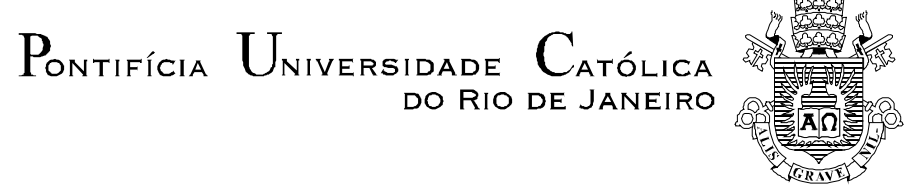

Rodrigo Ferreira das Neves

Aplicação dos Princípios e Ferramentas da Produção Enxuta (lean) Almoxarifado de uma Empresa do Setor de Óleo e Gás

Dissertação de Mestrado

Dissertação apresentada ao Programa de Pósgraduação em Engenharia Industrial da PUC-Rio como requisito parcial para obtenção do título de Mestre em Engenharia de Produção.

Orientador: Prof. Antônio Márcio Tavares Thomé

Co-orientador: Prof. Fernando Luiz Cyrino Oliveira

Rio de Janeiro

Agosto de 2015 
Rodrigo Ferreira das Neves

\title{
Aplicação dos Princípios e Ferramentas da Produção Enxuta (lean) Almoxarifado de uma Empresa do Setor de Óleo e Gás
}

Dissertação apresentada como requisito parcial para obtenção do título de Mestre pelo Programa de Pós-Graduação em Engenharia Industrial da PUC-Rio. Aprovada pela Comissão Examinadora abaixo assinada.

\author{
Prof. Antônio Márcio Tavares Thomé \\ Orientador \\ Departamento de Engenharia Industrial - PUC-Rio
}

Prof. Fernando Luiz Cyrino Oliveira

Co-orientador

Departamento de Engenharia Industrial - PUC-Rio

Prof. José Eugênio Leal Departamento de Engenharia Industrial - PUC-Rio

Prof. Adriana Leiras

Departamento de Engenharia Industrial - PUC-Rio

Prof. José Eugênio Leal Coordenador(a) Setorial do Centro Técnico Científico - PUC-Rio 
Todos os direitos reservados. É proibida a reprodução total ou parcial do trabalho sem autorização da universidade, do autor e do orientador.

Rodrigo Ferreira das Neves

Graduou-se em Engenharia de Produção pela (UFF) Universidade Federal Fluminense em 2002. Pós Graduado em Gestão de Negócios com ênfase em Tecnologia de informação em 2004 na Fundação Getúlio Vargas (FGV-RJ).

Ficha Catalográfica

Neves, Rodrigo Ferreira das

Aplicação dos princípios e ferramentas da produção enxuta (lean) almoxarifado de uma empresa do setor de óleo e gás / Rodrigo Ferreira das Neves; orientador: Antônio Márcio Tavares Thomé; co-orientador: Fernando Luiz Cyrino Oliveira - 2015.

85 f. ; $30 \mathrm{~cm}$

Dissertação (mestrado) - Pontifícia Universidade Católica do Rio de Janeiro, Departamento de Engenharia Industrial, 2015.

Inclui bibliografia

1. Engenharia Industrial - Teses. 2. Lean. 3. Almoxarifado. 4. Óleo e gás. 5. Mapa de fluxo de valor. I. Thomé, Antônio Márcio Tavares. II. Oliveira, Fernando Luiz Cyrino. III. Pontifícia Universidade Católica do Rio de Janeiro. Departamento de Engenharia Industrial. IV. Título. 
Aos meus pais (Antônio Carlos e Maria Edite)

e a minha esposa Patricia. 


\section{Agradecimentos}

Ao meu orientador, Prof. Antônio Márcio Tavares Thomé e ao co-orientador, Prof. Fernando Luiz Cyrino Oliveira, pelo incentivo e paciência durante a elaboração desta dissertação.

Aos professores que participaram da comissão examinadora.

Aos meus pais, pela educação e dedicação.

À minha esposa, pelo companherismo, incentivo e carinho.

Ao Raphael, que apesar de muito jovem, sempre contribuindo com seu incentivo.

A todos os amigos e familiares que, de certa forma, contribuíram para essa jornada. 


\section{Resumo}

Neves, Rodrigo Ferreira das; Thomé, Antônio Márcio Tavares (Orientador); Oliveira, Fernando Luiz Cyrino (Co-orientador). Aplicação dos princípios e ferramentas da produção enxuta (lean) almoxarifado de uma empresa do setor de óleo e gás. Rio de Janeiro, 2015. 85p. Dissertação de Mestrado (Opção profissional) - Departamento de Engenharia Industrial, Pontifícia Universidade Católica do Rio de Janeiro.

A aplicação dos conceitos do lean é uma prática originada na indústria automotiva utilizada inicialmente em áreas produtivas, permitindo ganhos de produtividade, através da redução de desperdícios nos fluxos de processo. Após o sucesso comprovado da utilização do lean em áreas produtivas, as organizações têm expandido a utilização deste conceito para outras áreas. O objetivo desta dissertação é aplicar a abordagem lean na revisão do fluxo de materiais de um almoxarifado, de uma empresa fabricante de equipamentos para o setor de óleo e gás. A metodologia utilizada tem dois componentes: uma revisão sistemática da literatura sobre o conceito lean e a pesquisa-ação através de um protocolo baseado em um modelo proposto para aplicação de estudos de caso em pesquisa-ação. Este trabalho descreve o processo de aplicação do lean. Os resultados alcançados foram a demonstração da viabilidade da aplicação dos princípios lean no almoxarifado, a identificação do fluxo de valor e do $5 \mathrm{~S}$ como as principais ferramentas de implementação, uma redução significativa dos tempos de fluxo do almoxarifado. As barreiras encontradas foram a concorrência do tempo das pessoas entre a pesquisa-ação e suas atividades rotineiras e o baixo envolvimento inicial dos setores interface com o almoxarifado (e.g., planejamento, compras e produção). Uma proposta baseada no mapa de fluxo de valor futuro para o fluxo de materiais no almoxarifado, migrando do modelo tradicional "empurrado" para o modelo enxuto, foi apresentada à empresa e está sendo considerada para implementação.

\section{Palavras-chave}

Lean; almoxarifado, óleo e gás; mapa de fluxo de valor. 


\section{Abstract}

Neves, Rodrigo Ferreira das; Thomé, Antônio Márcio Tavares (Advisor); Oliveira, Fernando Luiz Cyrino (Co-advisor). Applying the principles and tools of lean manufacturing (lean) in the warehouse of a company in the oil and gás sector. Rio de Janeiro, 2015. 85p. MSc Dissertation (Opção profissional) - Departamento de Engenharia Industrial, Pontifícia Universidade Católica do Rio de Janeiro.

The application of lean concepts is a practice originated in the automotive industry initially used in manufacturing areas, enabling productivity gains by reducing waste in the process flows. After the proven success of using lean in manufacturing areas, organizations have expanded the use of this concept to other areas. The aim of this work is to apply the lean approach in the review of the flow of materials from a warehouse in equipment's manufacturer for the oil and gas sector. The methodology used has two components: a systematic review of literature on the lean concept and action research through a protocol based on a proposed model for application of case studies on action research. This dissertation describes the lean application process. The results achieved to date demonstrate the feasibility of the application of lean principles in the warehouse, identifying the value stream and $5 \mathrm{~S}$ as the main implementation tools, and a significant reduction in warehouse's flow lead times. Barriers were found as competition of people's time between action research and their routine activities and the low initial involvement of sectors interfacing with the warehouse (eg, planning, purchasing and production). A proposal based on the map of future value stream to the flow of materials in the warehouse, migrating from traditional "pushed" to lean model, was presented to the company and is being considered for implementation.

\section{Keywords}

Lean; Warehouse; oil and gas; value stream mapping. 


\section{Sumário}

1 Introdução 11

1.1. Perguntas de pesquisa 12

1.2. Objetivos 13

1.3. Descrição do trabalho 14

2 Metodologia 15

2.1. Revisão sistemática da literatura 15

2.2. Pesquisa-ação 16

3 Fundamentação Teórica 18

3.1. Definições Gerais 18

3.1.1. Definição do termo lean 18

3.1.2. Princípios lean 20

3.1.3. Eliminação de desperdícios $\quad 22$

3.1.4. Tempo takt 23

3.1.5. Eficiência do fluxo $\quad 24$

3.2. Ferramentas 24

3.2.1. Mapa do fluxo de valor (MFV) 25

3.2.2. $5 \mathrm{~S} \quad 28$

$\begin{array}{ll}\text { 3.2.3. Kaizen } & 29\end{array}$

3.2.4. Total productive maintenance (TPM) 30

3.2.5. Plano para cada peça (PPCP) 31

3.2.6. Sistemas de entregas milk run 32

3.2.7. Controle visual 33

3.3. Implementação do lean 34

3.3.1. Barreiras ou obstáculos $\quad 34$

3.3.2. Benefícios 36

3.4. Operações de almoxarifado 37

4 Pesquisa-ação $\quad 39$

4.1. Apresentação da empresa $\quad 39$

4.1.1. Principais produtos 41

4.1.2. Modelo de operação 42

4.2. Proposta de aplicação lean no almoxarifado $\quad 47$

4.2.1. Mapeamento do estado atual 48

4.2.2. Mapeamento do estado futuro $\quad 54$

4.2.3. Trabalho padronizado $\quad 61$

4.2.4. Gestão Visual $\quad 62$

4.2.5. Controle do desempenho ao longo do fluxo 63

5 Conclusões e recomendações $\quad 64$

$\begin{array}{ll}6 \text { Referências bibliográficas } & 67\end{array}$

Apêndice I: Protocolo do estudo de caso 78 


\section{Lista de figuras}

$\begin{array}{ll}\text { Figura } 1 \text { - Ciclo da pesquisa-ação } & 17\end{array}$

Figura 2 - Caixa de dados padrão do MFV 28

Figura 3 - Organograma do almoxarifado 43

Figura 4 - Fluxograma atividades do almoxarifado $\quad 45$

Figura 5 - MFV Estado atual - fluxo de entrada 49

Figura 6 - MFV Estado atual - fluxo de saída 50

Figura 7 - MFV Estado futuro - fluxo de entrada 55

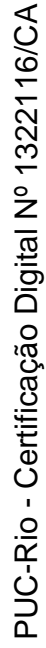

Figura 8 - MFV Estado futuro - fluxo de saída 56 


\section{Lista de tabelas}

$\begin{array}{ll}\text { Tabela } 1 \text { - Definições do termo lean } & 19\end{array}$

Tabela 2 - Ferramentas lean 25

$\begin{array}{ll}\text { Tabela } 3 \text { - Símbolos do fluxo de material } & 27\end{array}$

Tabela 4 - Princípios, conceitos e características Kaizen 30

Tabela 5 - PPCP (Plano para cada peça) 32

Tabela 6 - Barreiras para implementação do lean 35

Tabela 7 - Benefícios do lean 36

Tabela 8 - Distribuição de Part numbers por peso 45

Tabela 9 - Desperdícios Identificados $\quad 52$

Tabela 10 - Kaizens / práticas propostos por desperdício 54 


\section{Introdução}

A indústria de Óleo e Gás no Brasil vem passando nos últimos anos por grandes transformações. A descoberta de novos campos de hidrocarbonetos somada a comprovada viabilidade de produção nas reservas da camada pré sal trouxeram um enorme desafio para toda a cadeia produtiva, em especial para os fabricantes locais de equipamentos utilizados no processo de produção: expandir significativamente a capacidade produtiva em curto espaço de tempo.

A reserva de pré sal está localizada abaixo da camada de sal, um poço que pode atingir até 7000 metros de profundidade e que exige uma complexa e custosa engenharia para a retirada do óleo. A produção nesses campos obriga a indústria desenvolver equipamentos mais resistentes e a preços mais competitivos. Com isso, a necessidade de avanços tecnológicos, aprimoramento da indústria nacional, desenvolvimento da cadeia de suprimentos e qualificação de mão de obra são ações fundamentais a fim de garantir a expansão do setor no país. A descoberta de novas jazidas de pré sal alterou as perspectivas internas e externas em relação ao Brasil, alçando o país a uma posição de destaque, atraindo grandes investimentos para o setor, visando, sobretudo o aumento do seu volume de produção até 2020 .

Entretanto, o aumento de capacidade sempre que possível não deve vir acompanhado com aumento de custos. Caberá a maior demanda de equipamentos para os fabricantes que se notabilizarem pelo menor preço e menor prazo de entrega, além do atendimento aos requisitos técnicos do cliente. É importante mencionar que atrasos nas entregas de equipamentos são penalizados com multas contratuais podendo até mesmo comprometer toda viabilidade do negócio.

A partir do segundo semestre de 2014, um cenário desafiador tem se apresentado para a indústria do petróleo. A queda do preço do barril de USD 115,00 para valores abaixo de USD 60,00 (julho de 2015) tem feito com que empresas operadoras dos campos reavaliem sua estratégia, com foco na redução de custos, evitando assim, grandes perdas nas rentabilidades dos projetos. Esse cenário tem obrigado toda cadeia de fornecedores a revisitarem seus custos em face da nova realidade do mercado. 
Segundo a Agência Internacional de Energia (AIE, 2011), a demanda global de energia crescerá aproximadamente 45\% até 2030 e o petróleo ainda aparecerá com destaque na composição da matriz energética mundial, mesmo com o crescimento na utilização de energias renováveis.

Apesar de um aumento na oferta de energia renovável, petróleo e gás natural ainda exercerão um papel de destaque na matriz energética nacional, o que não significa uma redução na produção desses hidrocarbonetos já que a oferta adicional seria direcionada para o mercado externo (Tolmasquim, 2012).

A fim de que os desafios citados anteriormente sejam alcançados, faz-se necessária uma revisão completa na cadeia produtiva do óleo e gás, buscando o aumento de produtividade através da redução nos tempos de processos e da eliminação de gargalos. O conceito lean ou manufatura enxuta tem contribuído para que as empresas aumentem a produtividade através da eliminação de desperdícios ao longo da cadeia produtiva. Esta dissertação trata da aplicação do conceito lean na revisão do fluxo de materiais do almoxarifado de uma empresa fabricante de equipamentos do setor de óleo e gás através de uma pesquisa-ação baseada em um modelo proposto para estudo de caso.

\section{1}

\section{Perguntas de pesquisa}

A evolução da indústria de petróleo e gás tem impulsionado a demanda por equipamentos para a produção de hidrocarbonetos. O aumento do número de peças e partes utilizadas na produção de equipamentos tem resultado em aumento de estoques e consequentemente um maior fluxo de materiais nos almoxarifados das empresas do setor.

Face ao histórico de estoques elevados e a diversidade de tipos de partes e peças, o fluxo de almoxarifado é considerado crítico na cadeia produtiva do segmento. O ambiente competitivo tem trazido enormes pressões aos gestores de almoxarifado para que, simultaneamente, reduzam os tempos de processos e os custos operacionais que dependem do tamanho e do tipo de operação e estão relacionados ao custo de mão de obra e de utilização dos equipamentos (Frazelle, 2002; Tompkins et al., 2010 ; Huertas et al., 2007). 
O conceito de manufatura enxuta (lean), também conhecido como sistema Toyota de Produção, foi criado nos anos 60, na indústria automobilística japonesa visando prioritariamente à eliminação de desperdícios (Krafcik, 1988; Womack et al., 1990). Atualmente essa filosofia está amplamente estabelecida em várias empresas ao redor do mundo, com destaque nas indústrias automobilísticas e de eletroeletrônicos. Além da aplicação na manufatura, as empresas têm estendido com sucesso as aplicações do lean para outras áreas que compõem a cadeia produtiva, por exemplo: cadeia de suprimentos (Taylor, 2005) e desenvolvimento de novos produtos (Hines et al., 2006).

Esta dissertação visa responder às seguintes perguntas de pesquisa:

i. Os princípios e técnicas do lean podem ser aplicados com êxito em serviços logísticos de armazenagem?

ii. Quais as técnicas da manufatura lean que melhor se ajustam às necessidades de almoxarifado?

iii. Quais as principais barreiras ou obstáculos para a implementação de ferramentas lean no almoxarifado?

\section{2 \\ Objetivos}

A presente dissertação tem por objetivo geral aplicar a abordagem lean na revisão do fluxo de almoxarifado de uma empresa fornecedora de equipamentos para o setor de óleo e gás.

Os objetivos específicos são:

1. Apresentar a pesquisa-ação demonstrando a aplicação do conceito lean nas operações de almoxarifado de uma empresa do setor de óleo e gás.

2. Identificar as principais ferramentas lean que podem ser aplicadas a pesquisa-ação.

3. Estabelecer um plano de ação com recomendações, indicando as melhorias que poderão resultar da aplicação das ferramentas lean.

O presente trabalho explora um tema pouco presente na literatura, servindo de base para futuros estudos acadêmicos. Espera-se que, com a aplicação de seus 
resultados na empresa, resulte em uma redução dos tempos de ciclo, no estabelecimento de um fluxo enxuto de materiais e na redução do número de paradas desnecessárias no almoxarifado.

\section{3}

\section{Descrição do trabalho}

A partir dessa introdução, o Capítulo 2 apresenta a metodologia utilizada na dissertação tendo como componentes a revisão bibliográfica e a pesquisa-ação. Serão descritos a sistemática que serviu de base para a revisão bibliográfica e os passos utilizados na pesquisa-ação.

O Capítulo 3 é dedicado à revisão bibliográfica, onde estarão definidos os principais conceitos do lean e suas ferramentas. Além disso, serão apresentados os principais benefícios e barreiras para a implementação do lean. Este capítulo encerra-se com a descrição das principais operações de almoxarifado.

O Capítulo 4 referente à pesquisa-ação apresenta o segmento de óleo e gás, destacando as principais características do setor no Brasil, para introduzir a empresa, referenciando seus principais produtos, áreas de atuação e modelo de operação, com foco nas atividades de almoxarifado. E por fim, será apresentada uma proposta de aplicação do lean para o almoxarifado da empresa estudada, através da utilização de ferramentas do lean, com destaque para o mapa de fluxo de valor.

Finalmente, no Capítulo 5, são apresentadas as conclusões e recomendações finais da dissertação. 


\section{2 \\ Metodologia}

A metodologia utilizada para esta dissertação tem dois componentes: revisão sistemática da literatura e pesquisa-ação. Define-se revisão sistemática a partir de tradução própria da seguinte forma. "A revisão sistemática da literatura difere das revisões narrativas tradicionais, por adotar um processo replicável, científico e transparente ou, em outras palavras, uma tecnologia detalhada, que visa minimizar viés mediante buscas exaustivas da literatura, em estudos publicados e não publicados, propiciando um registro auditável das decisões, procedimentos e conclusões dos revisores” (Tranfield et al., 2003, p. 209). A pesquisa-ação é definida como sendo "tanto uma sequência de eventos quanto uma prática para solução de problemas. Como sequiência de eventos, inclui ciclos interativos de obtenção de dados, retroalimentando os interessados, analisando os dados, planejando a ação, agindo e avaliando, o que leva a coleta de dados adicionais, e assim por diante. Como prática de solução de problemas é uma aplicação científica do método de averiguação e experimentação a problemas práticos que requer soluções atuantes e que envolvam a colaboração e cooperação dos pesquisadores-ação e dos membros do sistema organizacional" (Coughlan \& Coghlan, 2002, p. 223).

\section{1}

\section{Revisão sistemática da literatura}

A revisão sistemática da literatura foi adaptada a partir de Thomé et al. (2012) e Thomé et al. (2014). Foram realizados os seis passos seguintes: (i) seleção das bases de dados bibliográficas digitais, (ii) identificação das palavraschave das buscas, (iii) definição dos critérios para exclusão de artigos, (iv) revisão manual de resumos selecionados, (v) revisão do texto completo dos artigos selecionados a partir dos resumos, (vi) busca das referências citadas nos artigos selecionados. 
As bases selecionadas foram o ScienceDirect e Emerald. Utilizou-se como palavras-chave "lean manufacturing and warehouse" sendo encontrados seis artigos no ScienceDirect e nenhum no Emerald, e apenas "lean manufacturing" com 422 artigos no Science Direct e 489 no Emerald. Ao todo, 489 resumos foram utilizados. No ScienceDirect a busca foi realizada nas palavras-chave, título e resumo, enquanto que no Emerald a busca foi feita apenas no resumo. Esta diferença ocorreu devido à parametrização dos sítios de busca da base de dados. Em ambas as bases não houve restrição do período de busca. Após a pesquisa, com base no resumo, foram excluídos os artigos com aplicações direcionadas a serviços (exceto logística), além dos duplicados.

O sétimo passo, que seria a busca de artigos que citaram os autores selecionados no passo (v), não foi realizado devido ao grande número de artigos pertinentes ao tema, já identificados nas etapas anteriores.

\section{2}

\section{Pesquisa-ação}

O protocolo de pesquisa-ação encontra-se no apêndice desta dissertação e seguiu o modelo proposto por Yin (2003) para estudos de caso. Um estudo de caso é definido como sendo "uma investigação empírica que pesquisa um fenômeno contemporâneo dentro de seu contexto da vida real, especialmente quando os limites entre o fenômeno e o contexto não estão claramente definidos”. (Yin, 2003, p. 32).

A pesquisa-ação caracteriza-se como sendo um estudo de caso no qual o investigador participa das atividades que estão sendo investigadas (Coughlan \& Coghlan, 2002).

A elaboração deste estudo de caso foi facilitada, com a participação ativa do autor como parte integrante da equipe do projeto, garantindo o acesso direto aos conceitos, discussões e informações. Além disso, o autor vivenciou todas as etapas do processo de implementação, desde a definição do escopo e equipe até as barreiras que surgiram durante a jornada em curso.

Os principais passos para realização da pesquisa-ação foram: elaboração do protocolo e identificação dos atores-chave no processo de armazenagem. A 
realização da pesquisa-ação seguiu as etapas preconizadas por Coughlan \& Coghlan (2002), segundo apresentado na Figura 1.

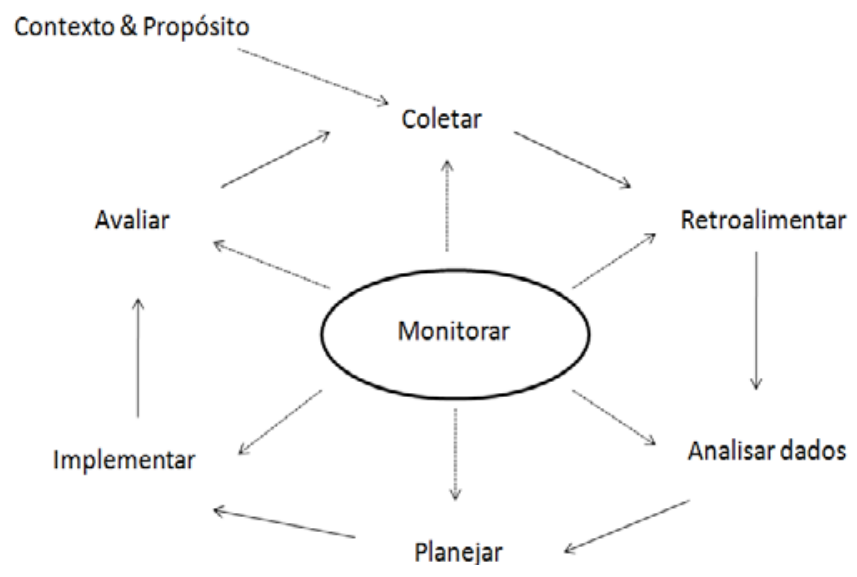

Figura 1- Ciclo da pesquisa-ação

Fonte: Adaptado de Coughlan \& Coghlan (2002).

Estas etapas são: (i) pré etapa - compreender o contexto e o propósito, (ii) seis etapas principais - coletar, retroalimentar e analisar os dados, planejar, implementar e avaliar a ação, (iii) meta-etapa para monitorar.

Na pré etapa foi realizada uma análise da empresa estudada contemplando seus principais produtos e modelo de operação conforme descrito na Seção 4.1. A seguir, os dados foram coletados inicialmente através do mapeamento do de fluxo de valor conforme pode ser visto nas Seções 4.2.1 e 4.2.2. Esses dados foram retroalimentados após o estudo de tempos e entrevistas com os operadores do fluxo de processo. Em seguida os dados foram analisados pela equipe do projeto, servindo de base para a etapa de planejamento onde os mapas de fluxo de valor do estado futuro foram revisados. A partir daí, o novo fluxo foi implementado e os resultados avaliados e monitorados. Toda essa sequência esta descrita no protocolo de estudo de caso no apêndice desta dissertação.

O foco da meta-etapa é a dissertação acadêmica. Os pesquisadores do projeto de pesquisa-ação questionam de que forma a nível organizacional os ciclos da pesquisa-ação podem ser implementados (Coughlan \& Coghlan, 2002, p.230). 


\section{3}

\section{Fundamentação Teórica}

Neste capítulo serão abordados os principais conceitos necessários à aplicação da pesquisa-ação. A primeira seção define os conceitos da filosofia lean com ênfase na eliminação de desperdícios, tempo takt e eficiência de fluxo. A Seção 3.2 apresenta as ferramentas do lean com foco nas utilizadas na pesquisaação. A Seção 3.3 aborda os principais benefícios e barreiras para a implementação do lean. Na última seção serão apresentados os conceitos básicos de operação de almoxarifado.

\section{1}

\section{Definições Gerais}

Esta seção trata da definição do termo lean, seus princípios, da eliminação dos desperdícios, assim como do tempo takt e da eficiência de fluxo.

\subsection{1}

\section{Definição do termo lean}

O termo lean foi utilizado pela primeira vez por Krafcik (1988), porém foi popularizado por Womack, Jones \& Ross (1990) ao descrever as práticas de manufatura do sistema Toyota de Produção, desenvolvido com a finalidade de se adaptar aos recursos escassos da economia japonesa após a segunda guerra mundial.

A Tabela 1 apresenta algumas definições do lean adaptadas a partir de Bhamu e Sangwan (2014). 
Tabela 1 - Definições do termo lean.

\begin{tabular}{|c|c|c|}
\hline & Autores & Definição \\
\hline 1 & Krafcik (1988) & $\begin{array}{l}\text { Usa menos em tudo, quando comparado a produção em } \\
\text { massa: metade do esforço humano, metade do espaço } \\
\text { físico de fábrica, metade do inventário em fabrica, } \\
\text { produzindo com menos defeitos uma produção maior e } \\
\text { com mais variedade. }\end{array}$ \\
\hline 2 & Ohno (1988) & $\begin{array}{l}\text { Uma filosofia de trabalho concebida com o objetivo de } \\
\text { evitar desperdícios a fim de obter ganhos de } \\
\text { produtividade e reduções de custos e assim alcançar e } \\
\text { eficiência. }\end{array}$ \\
\hline 3 & Womack et al. (1990) & $\begin{array}{l}\text { Um processo dinâmico direcionado a um conjunto de } \\
\text { princípios objetivando as melhores práticas através do } \\
\text { conceito de melhoria contínua. }\end{array}$ \\
\hline & Liker (1996) & $\begin{array}{l}\text { Propõe-se a responder de forma rápida a uma demanda } \\
\text { do cliente através da eliminação de desperdícios nos } \\
\text { processos produtivos. }\end{array}$ \\
\hline 5 & Womack \& Jones (1996) & $\begin{array}{l}\text { Um sistema que emprega menos recursos para alcançar } \\
\text { os mesmos resultados }\end{array}$ \\
\hline 6 & Cox \& Blackstone (1998) & $\begin{array}{l}\text { Filosofia produtiva que busca minimizar os recursos } \\
\text { (incluindo tempo) utilizados nas atividades da } \\
\text { organização. Isso resulta em identificar e eliminar as } \\
\text { atividades que não agregam valor. }\end{array}$ \\
\hline 7 & Singh (1998) & $\begin{array}{l}\text { Filosofia baseada no sistema Toyota de produção, que } \\
\text { tem como foco minimizar, através da redução dos } \\
\text { desperdícios, o tempo entre a colocação do pedido pelo } \\
\text { cliente até a entrega do produto final. }\end{array}$ \\
\hline 8 & Liker \& Wu (2000) & $\begin{array}{l}\text { Filosofia produtiva que busca garantir um produto de alta } \\
\text { qualidade no tempo e com o menor custo. }\end{array}$ \\
\hline 9 & Hopp \& Spearman (2004) & $\begin{array}{l}\text { Sistema integrado que realiza a produção de bens e } \\
\text { serviços a um custo mínimo. }\end{array}$ \\
\hline 10 & Worley (2004) & $\begin{array}{l}\text { Remoção sistemática de desperdícios por todos os } \\
\text { membros da organização a partir de todas as áreas do } \\
\text { fluxo de valor. }\end{array}$ \\
\hline 11 & $\begin{array}{l}\text { Shah \& Ward } \\
\text { (2007, p. 791) }\end{array}$ & $\begin{array}{l}\text { Um sistema sócio técnico integrado, cujo objetivo } \\
\text { principal é eliminar desperdícios, reduzindo ou } \\
\text { minimizando simultaneamente a variabilidade em } \\
\text { fornecedores, clientes e interna. }\end{array}$ \\
\hline 12 & Hallgren \& Olhager, (2009) & Programa visando o aumento de eficiência nas operações. \\
\hline 13 & Alves et al. (2012) & $\begin{array}{l}\text { Modelo em que as pessoas assumem o papel de } \\
\text { pensadores e a partir desse envolvimento promovem a } \\
\text { melhoria contínua, garantindo uma maior agilidade para } \\
\text { enfrentar as demandas de mercado e um ambiente de } \\
\text { mudanças. }\end{array}$ \\
\hline
\end{tabular}

Fonte: Adaptada a partir de Bhamu \& Sangwan (2014).

O foco principal do conceito lean é a valorização do cliente através de uma sistemática identificação e eliminação das atividades que não agregam valor e geram desperdícios (Resta et al., 2015). Desperdício é a utilização de recursos (mão de obra, material, equipamento) a mais do que necessário para adicionar valor a um produto (Alarcon, 1997). 
A transformação da produção artesanal para uma mais eficiente (enxuta) é abordada na publicação do livro intitulado: A máquina que mudou o mundo, escrito por Womack et al. (1990) (Melton, 2005). Womack et al. (1990) compararam o sistema automotivo de produção em massa com o sistema Toyota de produção, demonstrando que o segundo sistema requer um menor esforço humano, menor espaço físico e menor investimento.

A fim de se obter uma migração do sistema tradicional em massa para o modelo enxuto, Arlbjorn \& Freytag (2013) elencaram os pré-requisitos necessários: "produção padronizada, alto volume e ciclo de vida longo do produto.” Para Najem-Al et al. (2013) além de planejamento, visão e habilidades dos colaboradores, são necessários o envolvimento e o comprometimento da alta gerência.

Nesta dissertação foi adotada a definição de Shah \& Ward (2007, p. 791) porque ela enfatiza os aspectos de eliminação de desperdícios e de redução de variabilidade de processos, essenciais para a aplicação feita nesta pesquisa-ação. A aplicação dos conceitos de manufatura enxuta tem se consolidado como uma estratégia bem sucedida permitindo as empresas obterem melhoria nos seus processos, através da revisão de seus fluxos de materiais. Com isso é esperado ganhos operacionais e de eficiência que irão melhorar os resultados (CuatrecasasArbos et al., 2011; Zarei et al., 2011). Para Womack et al. (1990), o foco da manufatura enxuta deve estar associado a uma resposta rápida das necessidades dos clientes, garantindo uma produção com qualidade de maneira mais eficiente e econômica.

\section{1 .2}

\section{Princípios lean}

Os princípios da manufatura enxuta foram introduzidos através do sistema Toyota de produção (Shingo, 1989) e tem como foco principal a definição do valor do produto percebido pelo cliente (Sundar et al., 2014).

O conceito lean pode ser definido subdividindo-os em cinco categorias: valor, mapa de valor, fluxo, sistema puxado e perfeição (Womack \& Jones, 1996).

Ao conceituar valor, considera-se a utilidade do produto ao cliente. Ao se referir ao mapa de valor, o valor representa as atividades do processo produtivo. 
Em relação ao fluxo, a garantia que o produto percorra as etapas do processo continuamente é prioridade. No sistema puxado, é necessário que o processo produtivo esteja alinhado com a demanda do cliente. A produção deve seguir o ritmo da demanda ou takt time (conforme será discutido na seção 3.1.4). E por fim, a busca pela perfeição requer foco constante em atender as necessidades do cliente, buscando melhorias para alcançar padrão zero de defeitos (Staats et al., 2011).

De acordo com Raghavan et al. (2014), os cinco princípios do lean seguem os seguintes passos:

1) Especificar o valor para o cliente.

2) Identificar as etapas do fluxo de processo que agregam valor.

3) Criar um fluxo contínuo para os produtos.

4) Iniciar o fluxo de valor através do pedido do cliente.

5) Interagir os quatro princípios anteriores buscando a perfeição.

O principal pilar da manufatura enxuta é o conceito de valor. O enfoque principal de uma empresa deve ser a busca do entendimento das necessidades de seus clientes (Dora et al., 2013). Para tanto, Hines et al. (2004), examinou esta relação, afirmando que o valor está relacionado aos requisitos do cliente. Sendo assim, tudo que difere dos requisitos passa a ser definido como desperdício. Portanto, entender o valor do cliente é essencial a fim de garantir que mudanças na operação não gerem desperdícios (Julien \& Tjahjono, 2009).

Carlborg et al. (2013) comentam que a atenção dos gestores deve estar no fluxo de valor ao invés de ficar concentrada na utilização eficiente dos recursos disponíveis. Matt (2014) define fluxo de valor como uma seqüência de atividades requeridas para a manufatura de um produto, porém considerando apenas as que agregam valor, ou seja, que atendam aos requisitos do cliente. Carlborg et al. (2013) apresentam ainda um sexto principio, o da padronização, como pré requisito para implantar o processo de melhorias. As unidades padronizadas são comparáveis em relação às suas medidas e indicadores.

Demeter \& Matyusz (2011) comentam que a metodologia lean está presente tanto no nível estratégico quanto no operacional. No nível estratégico o foco está direcionado para o entendimento do valor para o cliente e identificar o 
fluxo de valor. No nível operacional está voltado para a eliminação de desperdícios e na garantia da melhoria contínua.

\subsection{3}

\section{Eliminação de desperdícios}

A redução de desperdícios é uma estratégia que serve de base para os princípios lean através da eliminação das atividades que não agregam valor ao processo, aumentando assim sua eficiência (Nabhani \& Shokri, 2009). Russel \& Taylor (1999), Chauhan \& Singh (2012) reforçam essa afirmação, mencionando que o desperdício não resulta em nenhum valor para o cliente apenas absorve recursos.

Para Arunagiri \& Gnanavelbabu (2014), a erradicação dos desperdícios é o maior desafio enfrentado pelos especialistas em processos de manufatura. Assim, ao evitar as perdas no processo produtivo, as empresas estarão aptas a reduzir seus custos bem como os tempos de processamento.

Os sete desperdícios clássicos definidos por Ohno (1988) são (Bhasin \& Burcher, 2006):
1) Superprodução
2) Espera
3) Transporte
4) Retrabalho
5) Inventário
6) Movimentações desnecessárias
7) Defeitos

A superprodução considera a produção sem pedidos ou sem nenhuma compensação para esse esforço, o desperdício real (Imai, 2001). Espera é definida de acordo com o tempo de fila, ou seja, o operador aguardando a próxima etapa do processo, o que caracteriza desperdício temporal (Liker, 2004). Transporte referese às movimentações de materiais entre as operações durante o processo e devem ser minimizadas devido ao risco de possíveis avarias e ao aumento do tempo total de processamento (Hicks, 2007). O mesmo autor define retrabalho como as 
operações extras de processamento e manuseio, ocasionadas por defeito, superprodução ou excesso de inventário. Inventário é classificado como desperdício quando não é utilizado diretamente no atendimento das ordens de clientes, incluindo estoque em processo, matérias primas e produto acabado (Hicks, 2007). Movimentações desnecessárias estão relacionadas aos operadores, que ficam ociosos ou simplesmente sem foco durante sua jornada de trabalho, tendo como conseqüência um déficit produtivo. Defeito é a produção de resultados não desejáveis sendo caracterizado como uma ineficiência. A reparação, o retrabalho, a sucata e a inspeção são fatores de desperdícios (Sternberg et al., 2013). Desperdícios adicionais foram identificados como, por exemplo, a não utilização da criatividade dos colaboradores (Liker, 2004).

\subsection{4}

\section{Tempo takt}

O tempo takt (takt time) refere-se ao ritmo com o qual partes ou componentes devem ser produzidos a fim de atender a uma demanda do cliente (Sundar et al., 2014). O tempo takt é utilizado para sincronizar o ritmo da produção com o ritmo de vendas, assim sendo, podemos defini-lo de maneira simplificada como a taxa com a qual os clientes estão comprando produtos da linha de processo (Singh et al., 2010; Yang et al., 2015).

O takt time é calculado dividindo a demanda do cliente pelo tempo disponível de trabalho. O tempo disponível de trabalho é calculado pelo tempo padrão do turno, multiplicado pelo número de turnos (Deif \& Elmaraghy, 2014).

$$
\text { TempoTakt }=\frac{\text { Demanda em unidades }}{\text { Tempo disponível de trabalho }}
$$

Wahab et al. (2013) destacam como objetivo maior a busca por maximizar o valor para o cliente, através da prática de produzir produtos alinhados com a taxa de demanda. Nesse contexto, Rahani \& Al-Ashraf (2012) afirmam que é importante mensurar o tempo takt devido aos custos e aos fatores de ineficiência de se produzir acima da demanda. Os autores citam excesso de armazenagem de 
produtos acabados e compra antecipada de matérias primas, como conseqüência de não adequação ao tempo takt.

\subsection{5}

\section{Eficiência do fluxo}

Um dos conceitos fundamentais da produção enxuta é o estabelecimento do fluxo contínuo. Rother \& Shook (1999) definem o fluxo contínuo como o ato de produzir uma peça de cada vez, com o item sendo transferido imediatamente do estágio atual de processo para o seguinte sem nenhuma parada (desperdícios) entre eles.

Seguindo esse contexto, a redução do lote de produção permite obter um melhor controle do fluxo, garantindo sua continuidade e evitando a criação de desperdícios (Jabbour et al., 2014). O fluxo contínuo deve ser estabelecido através de um sistema puxado que consiste na produção baseada no consumo real do cliente, ou seja, nada será produzido até que seja demandado pelo cliente final (Agus \& Hajinoor, 2012). De acordo com Sudar et al. (2014), a eficiência do fluxo contínuo depende da produção em pequenos lotes no ritmo do tempo takt. A necessidade de reposição é sinalizada através do sistema kanban, a fim de eliminar a superprodução de produtos. Kanban é um suporte visual de controle da produção com informações que regulam o fluxo de inventário e materiais (Lim et al., 2013), utilizado para controlar níveis de inventários em processo a fim de regular a produção (Rahman et al., 2013), funcionando como gatilho disparador de uma certa atividade produtiva (Gonzalez-R et al., 2012). Em um fluxo enxuto também é comum a utilização do conceito de supermercado (estoque controlado de peças entre duas estações da produção) para a programação da produção em um processo anterior (Rother \& Shook, 1999).

\section{2}

\section{Ferramentas}

Na literatura podem ser encontradas diversas ferramentas lean. AA Tabela 2 apresenta as ferramentas mais comuns, segundo Bhamu \& Sangwan (2014): 
Tabela 2 - Ferramentas lean.

\begin{tabular}{|l|l|}
\hline \multicolumn{1}{|c|}{ Ferramenta } & \multicolumn{1}{c|}{ Autores } \\
\hline Mapa de Fluxo de Valor & Hines et al (1998); Kumar et al (2006) \\
\hline Sistema Puxado e Kanban & Hines et al (1998); Shah \& Ward (2007) \\
\hline Just in Time & $\begin{array}{l}\text { Bayo-Moriones et al. (2008) ; Shah \& Ward } \\
(2007)\end{array}$ \\
\hline Total Productive Maintenance (TPM) & Hines et al. (1998); Jiménez et al. (2011) \\
\hline 5S & Jensen \& Jensen (2007) ; Jiménez et al. (2011) \\
\hline Manufatura Celular & Shah \& Ward (2007); Hodge et al. (2011) \\
\hline Melhoria Contínua & Wu (2003) ; Johansen \& Walter (2007) \\
\hline Kaizen & Jensen \& Jensen (2007); Wong et al. (2009) \\
\hline Nivelamento de Produção (Heijunka) & Hines et al. (1998) ; Wu (2003) \\
\hline Controle Visual & Wong et al. (2009); Jiménez et al. (2011) \\
\hline Poke Yoke & Wong et al. (2009) ; Hodge et al. (2011) \\
\hline Automação (Jidoka) & Hines et al. (1998) ; Pettersen (2009) \\
\hline Plano para Cada Peça (PPCP) & Rother \& Shook (1999) \\
\hline Milk Run & Nemoto et al. (2010) ; Danese et al. (2012) \\
\hline
\end{tabular}

Fonte: Adaptada a partir de Bhamu \& Sangwan (2014).

No entanto, serão descritas nesta seção apenas as ferramentas lean que foram utilizadas na pesquisa-ação: mapa de fluxo de valor, 5S, kaizen, TPM (total productive maintenance), PPCP (plano para cada peça), milk run e controle visual.

\section{2 .1}

\section{Mapa do fluxo de valor (MFV)}

O MFV nos permite visualizar todo o fluxo de processo produtivo (Singh \& Sharma 2009). De acordo com Tyagi et al. (2015), o MFV é uma plataforma visual que captura as entradas e saídas de todo o processo (porta a porta) considerando recursos, tempo de ciclo e tempo de utilização.

Segundo Taylor (2005), o MFV apresenta de forma resumida as características dos processos chave para toda a organização, permitindo aos gestores o entendimento das condições operacionais e visualização de oportunidades de melhorias (Jasti \& Sharna, 2014).

Rohac \& Januska (2015) afirmam que o resultado do mapa de fluxo de valor é um gráfico contendo o fluxo de toda a empresa, sendo possível identificar 
a etapa de acúmulo de inventário, o tempo total de produção e o percentual de tempo de valor agregado. Os processos pertencentes ao fluxo de valor devem ser divididos em dois grupos: adicionam valor (VA) e não adicionam valor (NVA). O objetivo do mapeamento do fluxo de valor é de identificar todos os tipos de desperdícios visando ações para eliminá-los e com isso, reduzir o lead time do processo. O lead time é o tempo que uma peça leva para se mover ao longo de todo um fluxo de valor (Rother \& Shook, 1999), ou seja, o intervalo de tempo entre o início e fim de uma atividade ou processo. O mapeamento é feito utilizando um papel e caneta com vários símbolos representando o fluxo de material e informação, conforme o produto percorre a linha de produção (Singh \& Sharma, 2009). Os principais símbolos utilizados nesta dissertação estão informados na Tabela 3. A coleta de informações para o desenho do fluxo de valor atual deve ser realizada no gemba. Gemba é uma palavra japonesa que significa o local onde o processo é executado, encorajando o princípio do "ir e ver” (Tyagi et al., 2015).

Segundo Rahani \& Al-Ashraf (2012) além de permitir verificar aonde ocorrem os desperdícios, o mapeamento de fluxo de valor auxilia na identificação de alguns fatores, conforme elencados a seguir:

- Etapas de processo.

- Métricas de processo.

- Inventário.

- Fluxo de materiais com o fornecedor.

- Informação e fluxo físico.

- Tempo takt e tempo total de ciclo.

Sundar et al. (2014) mencionam que o mapeamento do estado atual nos leva a identificação de gargalos, a partir da comparação entre o tempo takt (demanda do cliente) e o tempo de ciclo em cada etapa do processo. O tempo de ciclo é o intervalo de tempo entre duas produções em um mesmo processo (Rother \& Shook, 1999). Após o mapeamento do estado atual, o passo seguinte é o mapeamento do estado futuro baseado em um plano de melhorias. O mapa estado futuro é resultante das propostas de mudança identificadas na fase de mapeamento do fluxo atual (Tyagi et al., 2015). Teichgraber \& Bucourt (2012) comentam que o maior benefício do processo de mapeamento surge da criação: as idéias são levantadas, paradigmas são revistos e o consenso é construído. 
Tabela 3 - Símbolos do fluxo de material.

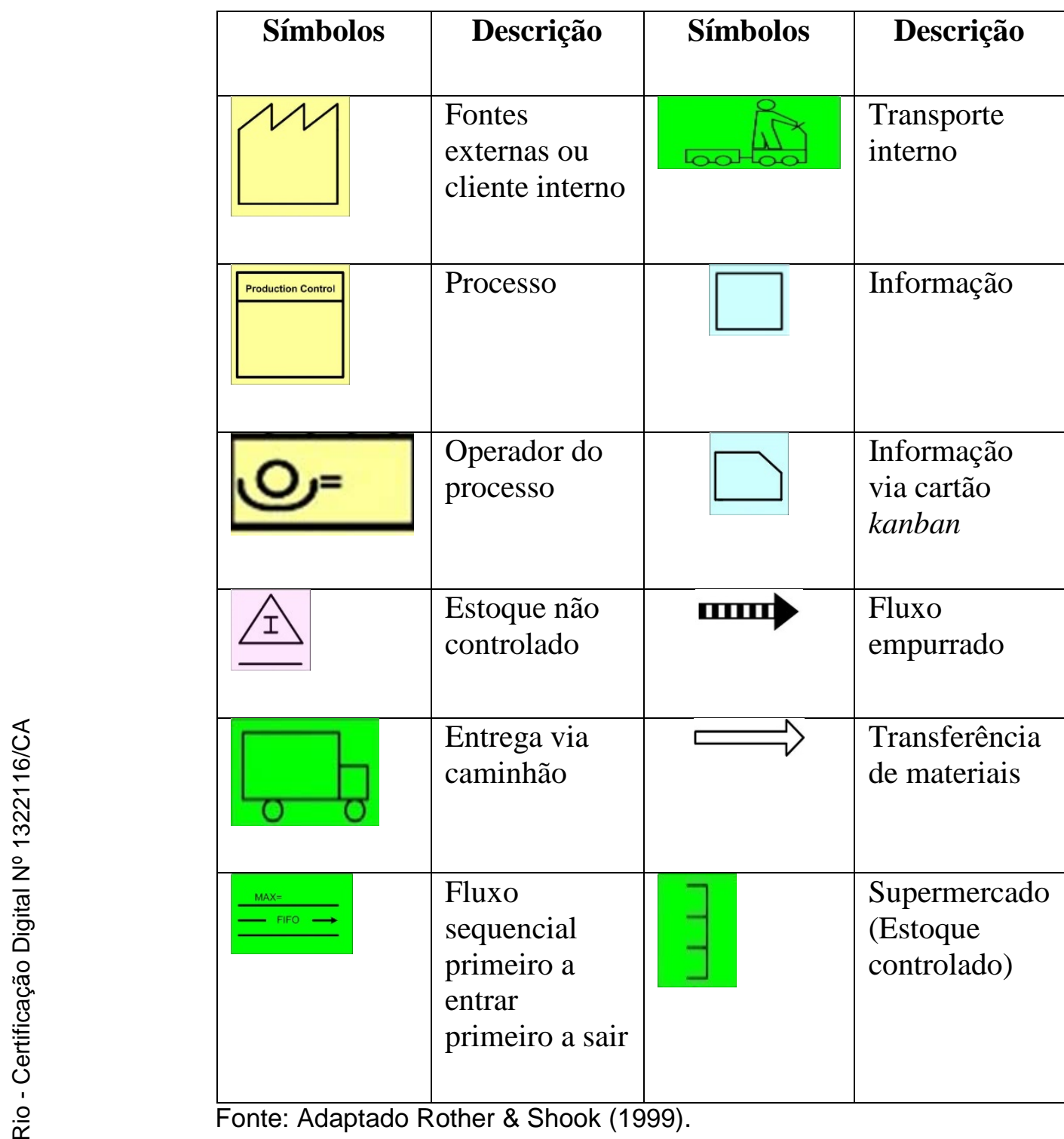

Além dos ícones citados acima, um símbolo importante utilizado no MFV é a caixa de dados que é utilizada para registrar os dados relativos a um processo: C/T (tempo de ciclo), P/T (tempo de processo ou atividade), C/O (tempo de troca ou set up), uptime (utilização), quality (atendimento a qualidade), \# of shifts (escala de trabalho), na Figura 2 o formato da caixa de dados. 


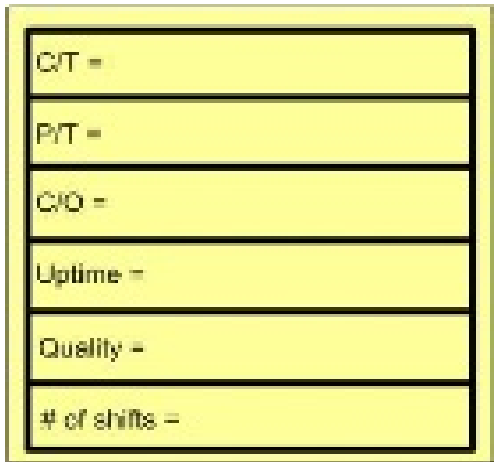

Figura 2 - Caixa de dados padrão do MFV.

\subsection{2}

$5 S$

Em um fluxo produtivo, frequentemente muito tempo é desperdiçado na busca por itens desaparecidos ou perdidos, com isso a primeira etapa de melhoria deve focar na organização e arrumação do ambiente de trabalho (Julien \& Tjahjono, 2009). O $5 S$ é um sistema que visa a redução dos desperdícios e o aumento da produtividade através da concepção de um ambiente de trabalho organizado e padronizado (Bayo-Moriones et al., 2010). O termo 5S é baseado nos termos em japonês seiri (organização), seiton (arrumação), seiso (limpeza), seiketsu (padronização) e shitsuke (disciplina), (Gapp et al., 2008).

Seiri (organização) é a primeira etapa do 5 S e o objetivo principal é eliminar itens desnecessários no local de trabalho (Gupta \& Jain, 2015). Seiton (arrumar) garante um lugar para cada parte, focando na segregação dos objetos e sua efetiva estocagem (Harrington, 2000). Seiso (limpeza) prioriza as atividades de limpeza e organização. Uma área organizada e limpa é um fator de motivação para os colaboradores. Seiketsu (padronização) visa garantir um alto padrão de organização do ambiente de trabalho (Gupta \& Jain, 2015). Shitsuke (disciplina) tem como objetivo sustentar a padronização alcançada que deve ser preservada de uma maneira efetiva (Harrington, 2000; Dudek - Burlikowask, 2006). Os autores sugerem auditorias regulares com pontuação para avaliação do nível de padronização das áreas.

Gapp et al. (2008, p. 566) destacaram os benefícios da utilização do conceito 5S: "Ordenação (seiri e seiton): maximizar a eficiência e eficácia reduzindo a carga de trabalho dos operadores e erros através da simplificação do 
processo. Limpeza (seiso e seiketsu): contribuir para uma vida mais saudável e segura. Disciplina (shitsuke): através de treinamento e educação a fim de aumentar a qualidade e o grau de padronização das atividades.”

Entre os principais benefícios da aplicação desta ferramenta estão: envolvimento dos colaboradores, aumento da eficiência, produtividade, qualidade e estabelecimento da cultura da organização e disciplina (Barraza-Suárez \& Ramis- Pujol, 2012).

No entanto, Gupta \& Jain (2015) alertam sobre os obstáculos que possam surgir durante a implementação do 5S, relacionados à resistência da equipe que tende a interpretar esse programa como acréscimo de tarefas as suas rotinas. A fim de remover esses obstáculos, os autores sugerem treinamentos e discussões de alinhamento com a equipe sobre os benefícios do programa.

Jiménez et al. (2015) destacam que a aplicação do conceito 5S conduz a uma melhor organização do local de trabalho, reduz o risco de acidentes. O autor sugere a adoção de um sexto “S”, relacionado à segurança.

\section{2 .3}

\section{Kaizen}

A ferramenta kaizen é largamente utilizada nas indústrias a fim de se obter uma excelência no processo produtivo (Singh \& Singh, 2009). Define-se Kaizen como conjuntos de melhorias gerados através da participação e o comprometimento de todos os colaboradores, desde a alta gerência até os envolvidos diretamente no processo (Watanabe-Magnier, 2011). A liberdade associada ao Kaizen estimula e desafia a criatividade dos operadores do chão de fábrica a propor melhorias e com isso, superar os problemas (Gondhalekar et al., 1995; Styhre, 2001). O objetivo do programa é o de assegurar a contínua implementação de melhorias, alavancar o trabalho em equipe e estimular a criatividade dos colaboradores visando a identificação e solução dos problemas (Gondhalekar et al., 1995). Na Tabela 4 estão listados os princípios, conceitos e características do Kaizen de acordo com Berger (1997). 
Tabela 4 - Princípios, conceitos e características Kaizen.

\begin{tabular}{|l|l|l|}
\hline \multicolumn{1}{|c|}{ Princípios } & \multicolumn{1}{|c|}{ Conceitos } & \multicolumn{1}{c|}{ Características } \\
\hline Orientado a processos & $\begin{array}{l}\text { Controle de processo através de } \\
\text { suporte e avaliação }\end{array}$ & $\begin{array}{l}\text { Treinar a força de trabalho em } \\
\text { métodos simples, utilizando as } \\
\text { habilidades e experiência existentes } \\
\text { na equipe }\end{array}$ \\
\hline Mudança em pequenas etapas & $\begin{array}{l}\text { Utilização de procedimento padrão é a } \\
\text { base para melhorias }\end{array}$ & $\begin{array}{l}\text { Disciplina, foco na melhoria do } \\
\text { padrão de trabalho através de } \\
\text { ferramentas de soluções de problemas }\end{array}$ \\
\hline Orientação a pessoas & $\begin{array}{l}\text { Utilizar grupos permanentes ou } \\
\text { temporários para a solução de } \\
\text { problemas }\end{array}$ \\
\hline
\end{tabular}

Fonte: Berger (1997).

Liker \& Convis (2011) classificam a ferramenta kaizen em dois tipos. O primeiro é o kaizen de manutenção que busca corrigir falhas inevitáveis de processo fim de garantir a retomada do processo padrão. O segundo tipo é o kaizen de melhoria que busca ganhos de produtividade no processo.

Shang \& Pheng (2013, p. 21) descrevem os três pré-requisitos para a implementação do conceito kaizen:

1) "Cultura e Valores: ambiente em que estimule os relatos de problemas e a inovação a fim de solucioná-los.”

2) "Padronização: as melhorias devem ser padronizadas a fim de consolidar o conhecimento visando à melhoria contínua.”

3) "Suporte Gerencial: deve estimular um ambiente propício, incentivando e a participação de todos e reconhecendo os melhores resultados.”

Yokozawa \& Steenhuis (2013) citam as vantagens da aplicação do kaizen: redução de custo, melhoria na produtividade, diminuição dos defeitos e aumento da motivação dos funcionários.

\section{2 .4}

\section{Total productive maintenance (TPM)}

Bhadury (2000) define TPM como um conceito inovador que busca a eficiência dos equipamentos eliminando paradas indesejadas ao promover a manutenção autônoma entre os operadores, tornando isso, parte de suas rotinas diárias. Segundo Ahuja \& Khamba (2008) a ferramenta tem como objetivo aumentar a competitividade das organizações através de um maior envolvimento 
dos colaboradores em todos os níveis a fim de maximizar a utilização dos equipamentos.

A indisponibilidade de equipamentos é um desperdício que precisa ser atacado. A adoção do TPM permite as organizações: aumento de produtividade, maior qualidade, menor custo, entregas confiáveis, um ambiente de trabalho mais seguro e um nível maior de motivação dos funcionários (Tripathi, 2005). Nesse contexto, Rolfsen (2014) comenta que além do foco tecnológico do equipamento, a literatura menciona também o trabalho em equipe e a cooperação multidisciplinar como características do TPM. Gardner (2000) reforça, afirmando que o engajamento da força de trabalho é um importante fator na redução de paradas não programadas e conseqüente aumento de lucratividade.

Ahuja \& Kumar (2009) elencam oito pilares que suportam o TPM: manutenção autônoma, manutenção planejada; qualidade; educação, treinamento e desenvolvimento de novas habilidades; melhorias individuais no equipamento; segurança, saúde e meio ambiente; controle administrativo; projetos de manutenção preventiva. Segundo Fuentes (2006), cada pilar pode ser avaliado. O pilar de manutenção autônoma lida com o envolvimento do operador pelo equipamento, o da manutenção planejada define critérios de manutenção, controle de inventário etc. Qualidade avalia o efeito do equipamento na conformidade dos produtos ou processos. O pilar de educação, treinamento e desenvolvimento de novas habilidades avalia a capacidade de recursos humanos envolvidos, verificando os treinamentos necessários, o de melhorias individuais busca a eliminação de perdas nos processos. O pilar de saúde, segurança e meio ambiente lida com as políticas de prevenção e análises de risco, o de controle administrativo envolve as áreas de suporte como, por exemplo, compras. Por último o pilar de projetos de manutenção, avalia a viabilidade de troca do equipamento considerando os custos atuais de manutenção.

\section{2 .5}

\section{Plano para cada peça (PPCP)}

O PPCP (plano para cada peça) é uma planilha que contempla um conjunto de informações referentes a uma peça específica, identificada através de um código único (part number). O objetivo é montar um banco de dados a fim de 
reunir em uma única tabela informações sobre as peças em estoque. As informações referentes à peça variam conforme necessidade de cada operação, geralmente as mais utilizadas são: fornecedor, lote e lead time de compra, demanda diária, quantidade por embalagem, peso, conforme exemplificado na Tabela 5.

Tabela 5 - PPCP (Plano para cada peça).

\begin{tabular}{|l|l|}
\hline \multicolumn{1}{|c|}{ Nome } & \multicolumn{1}{|c|}{ Descrição } \\
\hline Peça & $\begin{array}{l}\text { Número único utilizado para identificar cada peça (chave } \\
\text { primária). }\end{array}$ \\
\hline Descrição & Nome do Material (ex:rosca, parafuso, estrutura etc). \\
\hline Demanda diária & Quantidade de peças utilizadas diariamente. \\
\hline Local de uso & $\begin{array}{l}\text { Local ou parte do processo onde o material é utilizado (ex: célula } \\
\text { de montagem 10). }\end{array}$ \\
\hline $\begin{array}{l}\text { Local de } \\
\text { armazenagem }\end{array}$ & Endereço de estocagem no almoxarifado. \\
\hline $\begin{array}{l}\text { Freqüência de } \\
\text { pedido }\end{array}$ & Freqüência que uma ordem de compra é enviada ao fornecedor. \\
\hline Fornecedor & Nome do fornecedor. \\
\hline $\begin{array}{l}\text { Quantidade padrão } \\
\text { por embalagem }\end{array}$ & Quantidade de peças fornecidas em uma embalagem. \\
\hline $\begin{array}{l}\text { Utilização por } \\
\text { montagem }\end{array}$ & Quantidade de peças utilizadas na montagem de 1 produto final. \\
\hline
\end{tabular}

Fonte: Adaptado de Harris et al.(2004).

As informações contidas no PPCP estão, muitas das vezes, em vários sistemas, ou planilhas dispersas pela empresa. Garantir a centralização dessas informações em uma única tabela facilita a visualização e a gestão desses parâmetros. Essas informações serão úteis para dimensionar: volume de estoque, logística de entrega de materiais do fornecedor, local de armazenagem e a logística de reposição no ponto de uso. A manutenção deste plano é fundamental, sugere-se uma rotina de atualização para evitar a obsolescência das informações.

\subsection{6}

\section{Sistemas de entregas milk run}

O sistema de entregas milk run é caracterizado por múltiplas coletas de materiais em diferentes locais (fornecedores) por um único veículo, atendendo a uma política de agendamento (Chen \& Sarker, 2010). Para Danese et al. (2012) é utilizado para sincronizar e agregar múltiplas entregas. Milk run é o termo 
genérico para caracterizar uma consolidação de carga pelo comprador. Esse sistema originou-se da prática do entregador de leite que percorria uma rota entregando leite aos clientes e coletando as garrafas vazias. É muito utilizado pela indústria automotiva, que usa um determinado veículo (caminhão) em uma rota pré definida, visitando e coletando materiais de diferentes fornecedores e entregando-os na planta fabril (Nemoto et al., 2010).

Ainda de acordo com Nemoto et al. (2010), a utilização do milk run visa:

1) Transparência no custo de transporte.

2) Redução dos custos de transporte devido a consolidação de cargas.

3) Sincronizar o ritmo de produção com a retirada dos materiais nos fornecedores (reduzindo o estoque na planta fabril).

A aplicação desse sistema requer que os fornecedores estejam próximos uns dos outros, evitando que o veículo percorra grandes distâncias com capacidade ociosa, aumentado assim os custos de transporte.

\subsection{7}

\section{Controle visual}

A ferramenta de controle visual permite uma maior fluidez da informação pela planta produtiva através da utilização de painéis, quadros atualizados com indicadores chave (Martinéz-Jurado et al., 2014). De acordo com Gamme \& Aschehoug (2014), através do controle visual é possível identificar gargalos, garantir maior transparência e reagir rápido ao surgimento de problemas operacionais.

Um controle visual com sinais luminosos, também conhecido como andon, é bastante utilizado nas linhas de produção. Andon significa lanterna em japonês e o objetivo deste controle é sinalizar interrupção nas linhas de produção (Kattman et al., 2012). Ainda segundo o autor, painéis luminosos também são utilizados com informações em tempo real sobre o volume de produção em uma determinada linha. A taxa de demanda do cliente ou takt time também é exibida nesse painel a fim de garantir um nivelamento correto do volume de produção.

Olausson \& Berggren (2010) acrescentam que a ferramenta de controle visual permite que as expectativas dos processos estejam mais claras e a 
priorização de atividades seja gerenciada de forma mais simples. Para Hines et al. (2006), a ferramenta visual permite uma melhor comunicação entre os times. Gamme \& Aschehoug (2014) sugerem que a criação do sistema visual deve ficar a cargo dos colaboradores. Além disso, o sistema deve ser simples, utilizando cores e com foco nos controles de processo.

\section{3}

\section{Implementação do lean}

Esta seção descreve as principais barreiras ou obstáculos e os benefícios do lean encontrados na literatura.

\subsection{1}

\section{Barreiras ou obstáculos}

A implementação do conceito de manufatura enxuta não é uma tarefa simples e como qualquer mudança em uma organização requer habilidades para identificar e remover as resistências (Jadhav et al., 2014). As principais barreiras encontradas estão listadas na Tabela 6. 
Tabela 6 - Barreiras para implementação do lean.

\begin{tabular}{|c|c|}
\hline Barreiras identificadas na literatura & Autores \\
\hline Cultura & $\begin{array}{l}\text { Morgan (1997), Ohno (1988), } \\
\text { Emiliani (1998), Hunter (2004) }\end{array}$ \\
\hline Resistência operacional & $\begin{array}{l}\text { Baker (2002), Cocolicchio (2008), } \\
\text { Conner (2009), Jadhav et al. (2014) }\end{array}$ \\
\hline Custo de implementação & $\begin{array}{l}\text { Waurzyniak (2009), Henderson } \\
\text { \& Larco (2003), Ransom (2008) }\end{array}$ \\
\hline Sistema de comunicação interno & $\begin{array}{l}\text { Henderson \& Larco (2003), } \\
\text { Koltzenburg (2004), Dalal (2010), } \\
\text { Jadhav et al. (2014) }\end{array}$ \\
\hline Atitude dos colaboradores & Saurin et al. (2011) \\
\hline Resistência da alta direção & Jadhav et al. (2014) \\
\hline Baixo envolvimento da gerência sênior & $\begin{array}{l}\text { Houshmand \& Jamshidnezhad (2006) Jadhav } \\
\text { et al. (2014) }\end{array}$ \\
\hline Recursos ineficientes & Pedersen \& Huniche (2011) \\
\hline Rotatividade dos colaboradores & Shang \& Pheng (2014) \\
\hline Dificuldades da liderança em delegar & Liker (2004) \\
\hline
\end{tabular}

Axelsson et al. (2005) comentam que entre os principais motivos para a resistência da alta direção são: a falta de clareza, pressão e o receio pelo conceito novo. Houshmand \& Jamshidnezhad (2006) relacionam o baixo envolvimento da gerência sênior com a falta de estratégia, visão e direção da empresa, além disso, a comunicação deste grupo com os demais colaboradores também não é clara e os benefícios da manufatura enxuta não são informados a toda organização (Jadhav et al., 2014), contribuindo para uma resistência que é agravada com a preocupação de uma possível redução dos postos de trabalho (Wong et al., 2009). No entanto para Jadhav et al. (2014), as maiores barreiras estão relacionadas ao fator humano, cultural e os problemas organizacionais. Os autores reforçam ainda que a resistência a mudança é uma tendência natural da maioria das pessoas que não estão dispostas a sair da sua "zona de conforto" e que a implementação lean requer mudança na cultura e atitude. 
Muitas empresas focam na aplicação do conjunto de ferramentas lean, porém não obtêm sucesso, pois deixam de lado as relações humanas (Hines et al., 2004; Liker \& Rother, 2011). Ohno (1988) afirma que o lean não engloba apenas um conjunto de ferramentas, mas também o coração das pessoas.

\subsection{2}

\section{Benefícios}

Apesar da difusão da filosofia de manufatura enxuta em vários segmentos industriais, existe ainda uma dificuldade em mensurar sua contribuição na melhoria das organizações (Anvari et al., 2011). Alguns benefícios são listados na Tabela 7.

Tabela 7 - Benefícios do lean.

\begin{tabular}{|l|c|}
\hline \multicolumn{1}{|c|}{ Benefício } & \multicolumn{1}{|c|}{ Autores } \\
\hline $\begin{array}{l}\text { Redução de custos e eliminação de } \\
\text { desperdícios no fluxo de processos. }\end{array}$ & Lee \& Wei (2009), Pepper \& Spedding (2010) \\
\hline $\begin{array}{l}\text { Diminuição no tempo de processo e aumento } \\
\text { de produtividade. }\end{array}$ & $\begin{array}{l}\text { Lee \& Wei (2009), Pepper \& Spedding(2010), } \\
\text { Antony (2011) }\end{array}$ \\
\hline Aumento da lucratividade das organizações. & Bhasin (2012) \\
\hline Melhor utilização da força de trabalho. & Pepper \& Spedding (2010), Bhasin (2012) \\
\hline $\begin{array}{l}\text { Melhora nas condições de execução do } \\
\text { trabalho. }\end{array}$ & \multicolumn{1}{|c|}{ Bhasin (2012) } \\
\hline $\begin{array}{l}\text { Impacto favorável no trabalho em equipe e no } \\
\text { clima organizacional. }\end{array}$ & Pepper \& Spedding (2010), Calarge et al. \\
\hline $\begin{array}{l}\text { Ambiente voltado para a colaboração e (2004) } \\
\text { confiança. }\end{array}$ & \multicolumn{1}{c|}{ Melton (2005) } \\
\hline $\begin{array}{l}\text { Ganhos de capital de giro, aumento de } \\
\text { velocidade da cadeia de valor e redução nos } \\
\text { custos de manufatura. }\end{array}$ & Hofer et al. (2012), Agus \& Hajimoor (2012) \\
\hline $\begin{array}{l}\text { Baixo nível de inventário, alta qualidade e } \\
\text { desempenho operacional }\end{array}$ & Hofer et al. (2012), Agus \& Hajimoor (2012) \\
\hline $\begin{array}{l}\text { Diminuição da complexidade do planejamento } \\
\text { da produção }\end{array}$ & \multicolumn{1}{|c|}{ (2012) } \\
\hline
\end{tabular}

Fonte: adaptado de Lucato, et al., (2014)

O modelo lean requer profissionais pró-ativos e que estejam preparados e motivados para contribuir na sugestão de melhorias (Alves et al., 2012). Segundo Womack et al. (1990) o envolvimento da força de trabalho é essencial na criação de um ambiente de melhoria contínua. O “empoderamento” alinhado a capacidade de realização dos colaboradores tem se mostrado uma valiosa contribuição, 
resultando em impactos positivos no desempenho operacional (Taj \& Morosan, 2011).

\section{4}

\section{Operações de almoxarifado}

Os princípios e ferramentas do lean relatados nas seções anteriores serão aplicados na pesquisa-ação relacionada às operações de almoxarifado, descritas nesta seção.

As operações de almoxarifado são um componente essencial na logística e um fator chave na cadeia de suprimentos moderna, desempenhando um papel crítico no sucesso ou fracasso dos negócios (Frazelle, 2002). Almoxarifados são utilizados para estocar matérias primas, produtos em processo ou acabados entre o ponto de origem e consumo (De Koster, 2007). O almoxarifado desempenha um papel importante na cadeia de suprimentos, contribuindo para assegurar o nível de serviço desejado pelo cliente frente a possíveis incertezas na produção e flutuações de demanda. Lim et al. (2013) destacam ainda a possibilidade de economias de escala com a consolidação múltipla de pedidos em uma única entrega (transporte).

Uma operação típica de almoxarifado inclui as seguintes atividades: recebimento, armazenagem, separação de pedidos, embalagem e expedição (Tompkins et al., 2010). Gu et al. (2007) afirmam que recebimento e expedição são áreas que tem interface com o fluxo de chegada e saída de materiais. Ainda de acordo com os autores a atividade de recebimento é responsável por descarregar os materiais dos veículos nas docas de entrada. De Koster (2007) acrescenta ainda mais duas atividades para a área de recebimento: inspeção física e atualização dos registros de inventário.

O processo de armazenagem é descrito por Lim et al. (2013) como a transferência física do material da área de recebimento para as posições de estoque. A equipe de armazenagem deve garantir a guarda ou colocação do material no estoque além de maximizar a utilização do espaço (Gu et al., 2010). Em alguns casos é necessário um re-acondicionamento (troca de palete) ou reembalagem da carga antes da armazenagem (De Koster, 2007). 
Define-se separação de materiais (picking) como o processo de coleta de peças e partes em estoque em resposta a um requerimento específico do cliente interno ou externo (Goetschalckx \& Ashayeri, 1989; Tompkins et al., 2010). O requerimento do cliente é composto de linhas de pedidos, onde cada linha corresponde a um artigo em estoque e sua respectiva quantidade demandada (Henn \& Schmid, 2013). As atividades que compõem o processo de separação são: preparação, deslocamento, busca e coleta (Chan \& Chan, 2011).

Segundo Lam et al. (2011), o maior objetivo do processo de separação de pedidos é o de maximizar o nível de serviço, controlando as restrições de recursos, tais como mão de obra, máquinas e capital. Alguns fatores impactam diretamente no desempenho do processo de separação de materiais: leiaute, estratégia de armazenagem, políticas de rotas e o método de zoneamento (De Koster, 2007).

Berg \& Zijm (1999) comentam que uma política de alocação de estoque eficiente pode contribuir na redução do tempo de guarda e separação. Onüt et al. (2008) citam entre as políticas ou modelos de alocação de estoque mais utilizados: armazenagem aleatória, armazenagem dedicada e zonas de armazenagem. Na armazenagem aleatória, o material é endereçado para qualquer posição disponível no estoque. Na armazenagem dedicada, o material é alocado exclusivamente em posições previamente determinadas. No conceito de zonas de armazenagem, o material é direcionado para uma parte dedicada do armazém compatível com a sua classificação. Este último modelo é uma combinação de armazenagem aleatória com armazenagem dedicada.

Depois de concluído o processo de separação, os itens são transferidos para a área de expedição, onde é realizada a conferência, re-embalagem e carregamento em um veículo (Rouwenhorst et al., 2000). 


\section{Pesquisa-ação}

A empresa, objeto da pesquisa-ação é descrita neste capítulo, assim como seus produtos e modelo de operações com foco no almoxarifado. Os resultados obtidos com a aplicação das técnicas lean são apresentados em seguida.

\section{1}

\section{Apresentação da empresa}

A empresa estudada produz soluções tecnológicas complexas em âmbito mundial para o setor de energia, com foco no mercado de óleo e gás. Atua nos segmentos de processos submarinos (subsea), de superfície (surface) e infraestrutura em energia. Atualmente emprega cerca de vinte mil funcionários e tem presença consolidada nos cinco continentes.

Fundada no inicio da década passada, com sede nos Estados Unidos, originou-se da cisão de uma empresa, que fabricava equipamentos para os setores agrícolas, militares e energia. A empresa original atuava desde a década de trinta na produção de equipamentos para indústria de óleo e gás, o que permitiu à nova empresa uma vantagem competitiva, por incorporar esse histórico.

No segmento de processos submarinos, a empresa projeta e fabrica equipamentos utilizados pelos operadores nos campos de óleo e gás em águas profundas (abaixo de 700 metros da lâmina d'água). Os equipamentos são instalados no fundo do mar e tem como função principal controlar o fluxo e pressão dos fluídos desde os poços produtores (reservas) até as unidades processadoras (plataformas). Este segmento é o principal negócio da empresa correspondendo a $65 \%$ do faturamento médio dos últimos três anos e engloba também os serviços referentes à instalação dos equipamentos e suportes aos serviços no campo. A unidade de negócios de superfície projeta e fabrica equipamentos voltados para a produção em terra e águas rasas (até 700 metros de profundidade) que assim como no segmento de processos submarinos atua no controle de fluxo e pressão dos fluídos entre as reservas (cabeça de poço) e as 
unidades processadoras. O segmento de infraestrutura em energia projeta e produz soluções em medição, sistemas de carga e separação, automação e controle direcionados ao mercado de energia. Atualmente é a unidade de negócio com menor receita da empresa, representando $10 \%$ do faturamento médio dos últimos três anos, porém tem buscado através da aquisição de outras empresas um aumento de participação por entender a importância que este segmento representa dentro do mercado de energia.

O objetivo da empresa é prover soluções customizadas para seus clientes ao menor custo. Para tal, tem intensificado recentemente aquisições e associações com outras empresas visando à complementaridade dos seus produtos e serviços. O foco atual da empresa é o de integrar esses produtos criando um sistema único de soluções para o cliente e destacar-se pela expertise em tecnologia e engenharia, que é reconhecidamente a competência principal deste segmento.

\section{A empresa no Brasil}

Como parte da estratégia de crescimento em novos mercados e vislumbrando o crescimento do setor de hidrocarbonetos no país, a empresa optou por adquirir no inicio dos anos 2000 uma companhia de capital nacional com larga experiência na produção de equipamentos para indústria de óleo e gás. Ao longo dos últimos anos, a unidade do Brasil tem obtido relativa importância devido ao aumento da demanda por equipamentos para processos submarinos, visando atender às recém descobertas jazidas do pré sal. Com isso grandes investimentos foram realizados no seu parque fabril, localizado na região sudeste, permitindo um aumento de capacidade visando o atendimento dessa demanda. Entre os investimentos pode-se citar a aquisição de maquinas, aumento de instalações produtivas e construção de um novo almoxarifado. A empresa que tem atualmente cerca de dois mil funcionários investiu fortemente na capacitação destes através de treinamentos internos e intercâmbio com outras unidades da empresa, como no Reino Unido e Estados Unidos.

A fim de atender a demanda de equipamentos dos campos de pré sal, a empresa tem como desafio triplicar sua capacidade produtiva. Isso deverá ser alcançado não só com aumento das linhas de fabricação, mas também com melhora na produtividade através da redução no tempo total de manufatura. A 
empresa tem enfrentado uma forte concorrência de outras empresas multinacionais também instaladas no país, o que tem trazido como desafio a redução dos custos de produção e na diminuição do tempo entre a colocação do pedido pelo cliente e a entrega do produto final. O fornecedor de equipamentos que garantir o menor preço e tempo de entrega terá uma vantagem competitiva importante, podendo obter uma parcela maior de equipamentos demandados por seus clientes. Além disso, como usual no setor de óleo e gás, por força de contrato, qualquer atraso na entrega dos equipamentos é penalizado com uma multa, que pode resultar na perda da lucratividade do negócio.

A proximidade com o cliente em um momento de novas oportunidades como o pré sal e a política de conteúdo local são fatores que incentivaram investimentos não somente no parque fabril como também na criação de um centro de pesquisas buscando inovações no seu portfólio de produtos. O desenvolvimento de sistemas submarinos em campos localizados em águas ultraprofundas requer alto investimento por parte das operadoras. Nesse contexto, o estabelecimento de uma aliança com os clientes pode garantir além de entregas mais rápidas uma redução de custo desses sistemas. A empresa tem realizado uma importante aliança junto ao seu cliente principal na fase de projetos garantindo entendimento das reais necessidades com o objetivo de viabilizar uma solução especifica que minimize custos de produção dos equipamentos e maximize o volume de óleo e gás extraído dos campos.

\subsection{1}

\section{Principais produtos}

O foco desta seção está nos produtos de sistemas submarinos, uma vez que a pesquisa-ação focará nesta unidade de negócio unicamente.

O projeto e a manufatura dos sistemas submarinos requerem um elevado padrão de tecnologia e inovação. São sistemas capazes de suportar altas pressões hidrostáticas e temperaturas excessivas que podem alcançar 180 graus Celsius. As etapas de desenvolvimento de um sistema inclui mas fases de engenharia, design e plano de desenvolvimento do campo, como forma de considerar os aspectos e requisitos relevantes, entre os quais a otimização das perfurações (poços) e a arquitetura submarina. 
Os sistemas submarinos de produção são constituídos basicamente de válvulas e linhas de fluxo que regulam a produção de hidrocarbonetos através do monitoramento e controle da vazão, pressão e temperatura dos fluídos. Além disso, a utilização desses sistemas contribui para o aumento na taxa de recuperação e extensão da vida útil de um campo de produção de óleo e gás.

\subsection{2}

\section{Modelo de operação}

A área operacional da empresa é composta de uma fábrica de usinagem, onde são produzidas as peças nobres que serão utilizadas nos equipamentos, um setor de produção onde são realizadas as montagens dos equipamentos e o almoxarifado central onde são recebidas, inspecionadas e armazenadas as peças oriundas de fornecedores e da fábrica de usinagem.

O setor de produção é dividido por linhas de produto. Cada linha de produto apresenta uma estrutura organizacional independente com áreas de Planejamento e controle da produção (PCP), Qualidade, Produção e Engenharia. Isso ocorre devido à especificidade de cada produto, que apresentam demandas de mercado, processos de engenharia e montagem diferentes e independentes. A fábrica de usinagem e o almoxarifado atuam como unidades de serviços compartilhados para as linhas de produto.

A área de almoxarifado central integra a diretoria de produção e logística, e tem como principais atividades: receber, armazenar, separar e enviar as peças para as linhas de produção. Atualmente atuam na área sessenta colaboradores próprios e dez terceiros. A empresa tem contrato com uma prestadora de serviço que fornece mão de obra de operador de empilhadeira e auxiliar de almoxarifado. A operação do almoxarifado é realizada em dois turnos (Segunda a Sexta) das 6:00h às $0: 50 \mathrm{~h}$. No entanto, $80 \%$ do efetivo está alocado no horário diurno entre 6:00h e 17:00h.

Os colaboradores próprios estão organizados conforme organograma representado na Figura 3. 


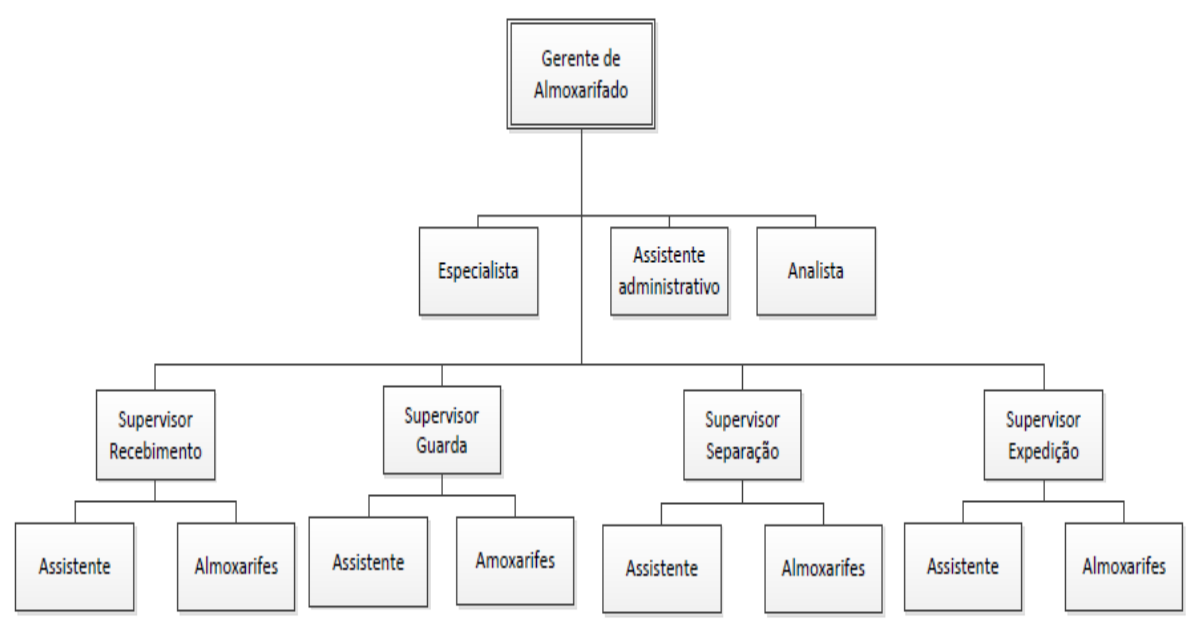

Figura 3 - Organograma do almoxarifado.

O prédio do almoxarifado é divido em três partes: área de escritórios, pátio interno de operação e o armazém.

A área de escritórios é composta de dois pavimentos com cerca de 1200 metros quadrados, onde estão alocadas as estações de trabalho da administração (gerência, supervisão, analistas, etc) e as salas de reunião e de treinamento. A área de operação ou pátio interno possui cerca de 1600 metros quadrados, sendo o local onde são realizadas as atividades de recebimento, inspeção e separação de materiais. O fluxo de entrada dos materiais é realizado através de uma doca única de recebimento e para a saída dos materiais (expedição) é utilizado um portão localizado no lado oposto à doca de recebimento. Este leiaute garante um maior controle nos fluxos de entrada e saída de materiais, uma vez que são realizados por docas exclusivas.

O armazém possui uma área de 3000 metros quadrados com pé direito de 12 metros, dispondo de 5000 posições paletes, distribuídos em cinco corredores (ruas). A estrutura do armazém é do tipo auto portante, ou seja, as colunas das estantes porta paletes, servem de sustentação para a cobertura do armazém. Este fato garante uma maior área útil de estocagem, uma vez que não há colunas estruturais de sustentação, entretanto, esse tipo de solução não permite alterações no leiaute do armazém. Uma área anexa ao armazém de 600 metros quadrados é dedicada a peças manuseáveis, que são armazenadas em pequenas gavetas, cestos ou nichos. Esta área é conhecida internamente como "gaveteiro”, e no momento é 
composto por cerca de 6000 unidades de armazenagem (bins), ou seja, gavetas ou cestos. Essa área inclui ainda uma sala refrigerada para materiais (borrachas, sistemas de controle, computadores, etc) que requerem condição diferenciada de armazenagem, conforme requisito técnico.

O almoxarifado dispõe ainda de uma área externa, de 8000 metros quadrados onde são armazenadas grandes estruturas, material de forjaria e alguns equipamentos prontos que aguardam a entrega ao cliente.

Atualmente a área de almoxarifado é responsável pela armazenagem de 4520 materiais (part numbers), composto de peças de pequenos centímetros e gramas, como arruelas e parafusos, até grandes estruturas com peso de cinco toneladas, movimentadas apenas por guindastes. Essa diversidade de peças está demonstrada na Tabela 8. A empresa utiliza um sistema de gestão de informação integrado (ERP), que conecta as operações em todas as unidades, a nível global. As operações de almoxarifado são controladas através da utilização do módulo de gestão de almoxarifado (Warehouse Management), garantindo o registro de todas as movimentações realizadas pelo time de operação. Recentemente a empresa implementou um sistema de código de barras 2D a fim de garantir maior acurácia e velocidade nas operações. Esse sistema está conectado ao ERP e permite que as operações de almoxarifado sejam realizadas de maneira automática utilizando apenas o leitor de barras.

Como forma de garantir o fluxo de materiais, a área dispõe de quatro empilhadeiras elétricas, sendo três com capacidade máxima de duas toneladas e uma articulada com capacidade de até cinco toneladas que são conduzidas por operadores dedicados a esta atividade. A movimentação de peças no pátio interno é realizada por paleteiras elétricas e manuais, com capacidade máxima de 1,5 toneladas, e são operadas pelos almoxarifes e auxiliares. No pátio externo, são utilizados guindastes padrão (munck) com capacidade útil de quinze toneladas. Para as peças ou equipamentos que excedam essa capacidade, a empresa aluga o equipamento. 
Tabela 8 - Distribuição de Part numbers por peso.

\begin{tabular}{|c|c|c|}
\hline Peso (kg) & $\begin{array}{c}\text { Quantidade de part } \\
\text { numbers }\end{array}$ & \% Total de estoque \\
\hline 0 a $20 \mathrm{~kg}$ & 2074 & $46 \%$ \\
\hline 21 a $50 \mathrm{~kg}$ & 439 & $10 \%$ \\
\hline 51 a $100 \mathrm{~kg}$ & 298 & $7 \%$ \\
\hline 101 a $200 \mathrm{~kg}$ & 315 & $7 \%$ \\
\hline 201 a $500 \mathrm{~kg}$ & 429 & $9 \%$ \\
\hline 501 a $1000 \mathrm{~kg}$ & 266 & $8 \%$ \\
\hline 1001 a $3000 \mathrm{~kg}$ & 376 & $2 \%$ \\
\hline 3001 a $5000 \mathrm{~kg}$ & 118 & $5 \%$ \\
\hline Acima de $5000 \mathrm{~kg}$ & 205 & \\
\hline
\end{tabular}

A seguir, temos a descrição das principais operações realizadas no almoxarifado, conforme fluxograma abaixo (Figura 4).

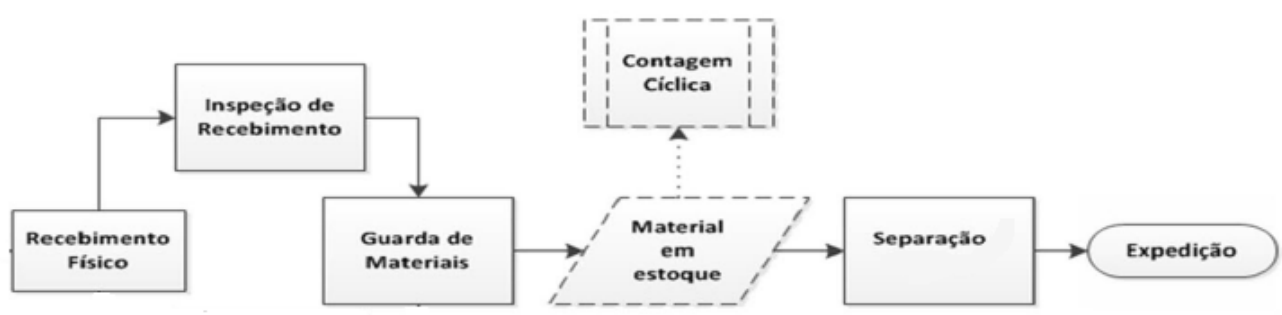

Figura 3 - Fluxograma atividades do almoxarifado.

\section{Recebimento}

O setor de recebimento é responsável por descarregar e conferir o material recebido de fornecedores. Esta conferência é feita confrontando o pedido de compra existente no sistema com a nota fiscal emitida pelo fornecedor. A área tem a função de identificar os materiais com a etiqueta de código de barra, além de desembalar os materiais que necessitem de inspeção física. Para os materiais de grande porte o recebimento é realizado no local de estocagem (pátio externo). 


\section{Guarda ou Armazenagem}

Este setor tem a atribuição de garantir o correto acondicionamento e endereçamento dos materiais no estoque. O fluxo de guarda se inicia com a retirada dos materiais liberados da área de inspeção, em seguida uma conferência é realizada pelo almoxarife que deve garantir que os paletes oriundos do fornecedor atendam as dimensões das estantes (porta paletes), caso contrário deve efetuar a troca do palete. O sistema (ERP) sugere um endereço (local) disponível para armazenagem, no entanto, o almoxarife deve verificar oportunidades de agrupamento com peças em estoque, ou seja, juntar as peças recebidas com peças em estoque em um único endereço (palete, gaveta ou nichos) minimizando assim a taxa de ocupação do almoxarifado. Por fim, o palete é destinado a uma área disponível para a coleta do operador de empilhadeira que o armazena conforme endereço disponibilizado pelo almoxarife. Para os materiais de gaveteiro, a guarda é feita pelo próprio almoxarife.

\section{Separação}

Ao receber uma demanda da área de planejamento, o setor de separação deve realizar a retirada dos materiais do estoque conforme lista de necessidades da ordem (picking list), conferir a rastreabilidade (números de série e lotes) dos materiais, realizar a baixa do material em estoque e disponibilizá-los para o setor de expedição.

\section{Expedição}

O setor de expedição deve garantir a entrega dos materiais no ponto de utilização (linhas de produção), após a liberação da área de separação. Devido a distância entre o almoxarifado e as linhas produtivas (são prédios independentes distantes em até 700 metros), a distribuição dos materiais é feita por um veículo com vagões acoplados onde são acondicionados os paletes com as peças. A exceção é feita para os materiais de grande porte que são transportados em caminhões dedicados, e movimentados com auxílio de guindastes. 


\section{Contagem Cíclica}

Com o objetivo de garantir a acurácia do estoque físico frente ao registro contábil no sistema ERP, a empresa realiza, através de uma equipe dedicada, a contagem cíclica do estoque. Seguindo uma classificação baseada no custo unitário e tempo de reposição do item pelo fornecedor, os materiais são contados de uma a até quatro vezes ao ano. Os itens mais nobres (maior custo e tempo de reposição) são classificados como “A”, e contados todos os trimestres. Esses itens correspondem a 8\% dos part numbers atualmente em estoque. Os itens "B” são contados uma vez por semestre e representam 35\% do estoque e os " $\mathrm{C}$ " uma vez por ano, correspondendo a $57 \%$ do estoque.

Além das atividades citadas acima, há a inspeção de recebimento físico que é uma atividade realizada pela área de Garantia da Qualidade e que visa verificar a conformidade das peças recebidas com os requisitos de engenharia. Essa atividade ocorre depois de concluído o processo de recebimento físico e antes da etapa de armazenagem. Caso a inspeção detecte alguma não conformidade, todo o lote recebido é direcionado para uma área segregada, específica para a armazenagem de materiais não conformes para que se busque uma tratativa junto ao fornecedor.

Entre os principais indicadores de desempenho da área estão: o tempo de processo entre o inicio do recebimento físico e a disponibilidade do material em estoque (dock to stock), o tempo de processo entre a solicitação de um material do estoque e a entrega na linha de produção (stock to asssembly) e a acurácia do estoque obtido através do processo de contagem cíclica. O resultado desse último indicador mede a aderência aos procedimentos da área, uma vez que falhas na armazenagem ou baixa de materiais comprometem a acurácia do inventário.

\section{2}

\section{Proposta de aplicação lean no almoxarifado}

Nesta seção será apresentada a aplicação do conceito lean no almoxarifado da empresa estudada visando obter ganhos de produtividade, melhora nos indicadores de desempenho e redução do custo de operação. 


\subsection{1}

\section{Mapeamento do estado atual}

O mapeamento do estado atual foi possível a partir da realização de entrevistas com os supervisores e operadores (almoxarifes) e da observação própria do fluxo de materiais e dos processos da área. Não foi utilizada a análise de dados históricos.

As Figuras 5 e 6 trazem o MFV com os fluxos de entrada (inbound) e de saída (outbound).

\section{Cálculo do tempo takt}

Antes de iniciar o mapeamento dos fluxos de valores, deve ser calculado o tempo takt para cada fluxo (entrada e saída). O cálculo do tempo takt permite dimensionar de maneira precisa a frequência ou ritmo necessário para o fluxo de materiais. O cálculo do tempo takt está baseado na Fórmula (1), apresentada no Capítulo 3.

Para o processo de entrada, o tempo takt é calculado utilizando os seguintes parâmetros: demanda de peças recebidas e horas trabalhadas. A previsão é que sejam recebidos 21500 peças por ano (média) distribuídas em 240 dias úteis. Considerando um turno apenas de trabalho (8 horas diárias), temos 1920 horas disponíveis ao ano. Aplicando a Fórmula (1), o tempo takt é de 5,4 minutos, ou seja, é necessário armazenar uma peça a cada 5,4 minutos.

Para o processo de saída, o tempo takt é calculado da mesma forma. Os parâmetros são: demandas de ordens de produção e horas trabalhadas. A previsão é uma demanda de 2200 ordens por ano. O fluxo de saída trabalha em dois turnos, totalizando 16 horas diárias. Com isso, aplicando a Fórmula (1), o tempo takt é de 105 minutos, ou seja, é necessário enviar uma ordem para a produção a cada 105 minutos. Esses valores constam nos mapas de fluxo do estado atual e futuro. 


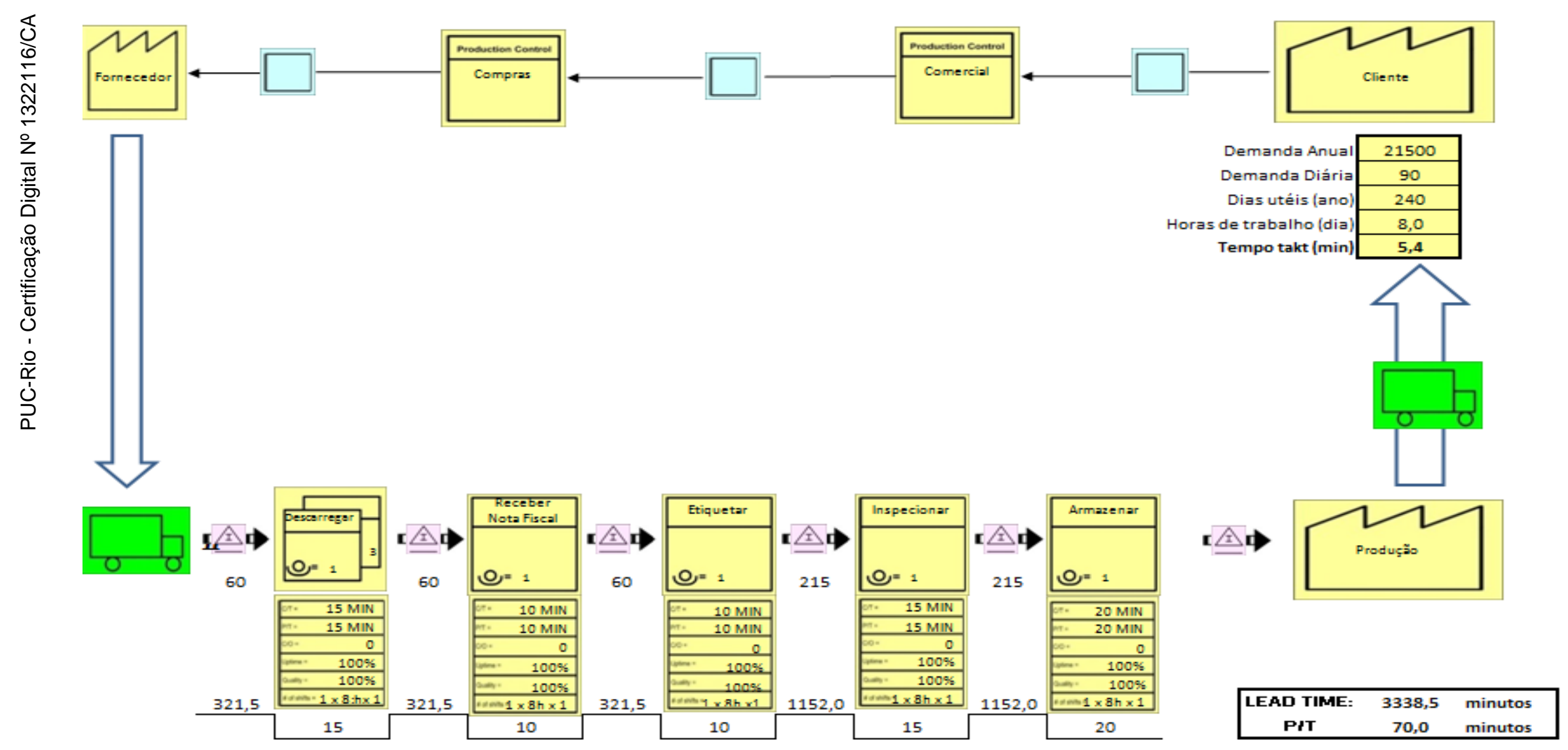

Figura 5 - MFV Estado atual - fluxo de entrada. 


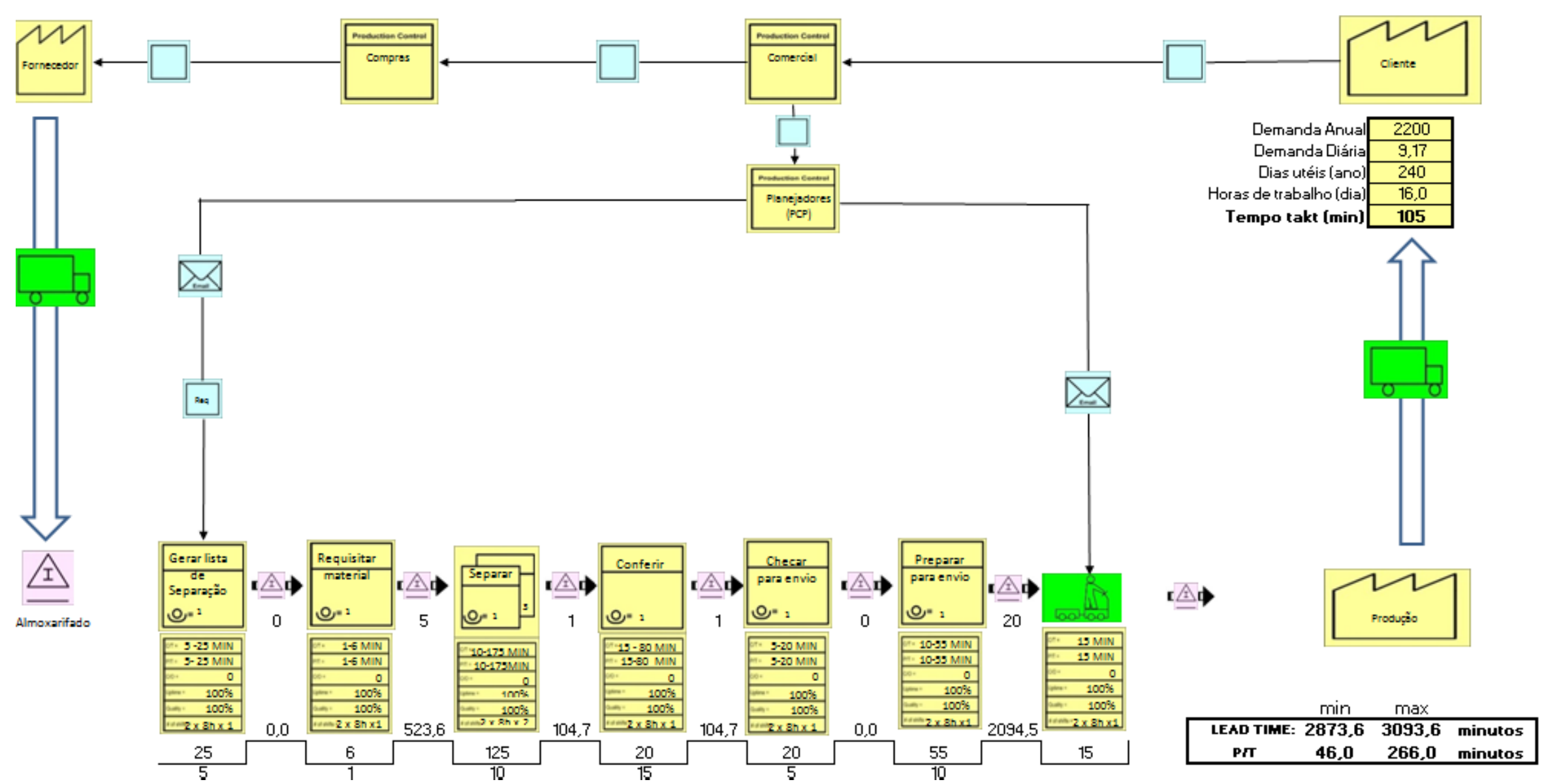

Figura 6 - MFV Estado atual - fluxo de saída. 


\section{Estado atual - fluxo de entrada}

O mapa do estado atual do fluxo de entrada está representado na Figura 5. O fluxo de entrada inicia-se com a colocação de um pedido de compra pelo cliente, que é introduzido pela área comercial no sistema computacional de gestão da empresa. A área de compras recebe, através do sistema computacional, as demandas de materiais necessárias para a produção dos equipamentos que compõem o pedido do cliente. Baseado nessas demandas, a área de compras envia através do sistema computacional ou correio eletrônico, os pedidos de compra para os fornecedores, contendo uma data prevista para recebimento. O fornecedor entrega o material diretamente no parque fabril (almoxarifado central). A concentração de entregas em um mesmo período gera uma fila de veículos para a descarga, ocasionando espera de cerca de 5 horas em média.

A próxima etapa do fluxo é a descarga do material que engloba a atividade de conferência física dos volumes recebidos. Em seguida, o veículo é liberado e os materiais são direcionados para o pátio interno, onde aguardam o processo de recebimento da nota fiscal. A atividade de recebimento de nota fiscal é composta pela verificação dos dados da nota e entrada desta no sistema computacional. Após o recebimento, o sistema gera automaticamente a etiqueta de identificação do material que serão colocadas individualmente nos materiais. Observa-se no fluxo uma espera (fila) de materiais de até dois dias entre o fim da atividade de etiquetagem e o inicio da atividade de inspeção. Após a liberação do material pela inspeção, observa-se uma espera de cerca de dois dias, até que seja iniciado o processo de armazenagem. Em alguns momentos, a falta de espaço disponível para armazenagem contribui para aumentar este tempo de espera.

\section{Estado atual - fluxo de saída}

O mapa do estado atual para o fluxo de saída esta representado na Figura 6. O fluxo de saída inicia-se com a solicitação da área de planejamento e controle da produção (PCP) para a separação de materiais que compõem uma determinada ordem de produção. Essa solicitação é feita via sistema computacional e em paralelo um email também é enviado para a supervisão do almoxarifado. A supervisão do almoxarifado cria uma lista de separação através do sistema 
computacional e em seguida requisita a separação aos almoxarifes. Uma fila de aproximadamente 8 horas é criada aguardando disponibilidade de recursos (máquinas e pessoas) e espaço físico disponível para o inicio da separação. Além da fila de espera, há a necessidade de espaço disponível para acomodar os materiais que serão separados. Após a atividade de separação, o almoxarife realiza uma conferência dos materiais separados e em seguida libera os materiais para envio pela área de expedição. A área de expedição realiza nova conferência, prepara os materiais para envio e aguarda a notificação do PCP para envio para a montagem. Durante a espera para envio para área de fabricação ocorre um acúmulo de materiais separados no almoxarifado.

\section{Principais desperdícios identificados}

Durante a fase de mapeamento e análise do estado atual (após mapeamento), a equipe do projeto identificou alguns dos principais desperdícios que prejudicam o estabelecimento de um fluxo enxuto de materiais ao longo das operações de almoxarifado. Esses desperdícios foram identificados baseados na definição de Ohno (1998), apresentada na revisão bibliográfica do Capítulo 3. Os principais desperdícios identificados estão descritos na Tabela 9.

Tabela 9 - Desperdícios identificados.

\begin{tabular}{|l|l|}
\hline \multicolumn{1}{|c|}{ Desperdício } & \multicolumn{1}{|c|}{ Descrição } \\
\hline Entregas de fornecedores não balanceadas. & $\begin{array}{l}\text { Filas de veículos no entorno da planta fabril e } \\
\text { jornada extraordinária da equipe do } \\
\text { recebimento. }\end{array}$ \\
\hline $\begin{array}{l}\text { Excesso de movimentação dos almoxarifes em } \\
\text { busca de ferramentas. }\end{array}$ & Interrupção de uma determinada atividade. \\
\hline $\begin{array}{l}\text { Disponibilidade insuficiente dos equipamentos } \\
\text { de movimentação. }\end{array}$ & $\begin{array}{l}\text { Espera por ausência de equipamentos } \\
\text { disponíveis. }\end{array}$ \\
\hline Alta ocupação do almoxarifado. & $\begin{array}{l}\text { Bloqueio no fluxo de armazenagem devido a } \\
\text { falta de posições disponíveis. }\end{array}$ \\
\hline Acúmulo de materiais na área de separação. & $\begin{array}{l}\text { Interrupção do processo de separação por falta } \\
\text { de espaço. }\end{array}$ \\
\hline
\end{tabular}

\section{Entregas de fornecedores não balanceadas}

As entregas de fornecedores sem agendamento prévio ocasionam grandes filas de veículos no entorno da planta fabril, aumentando os riscos de acidentes. Além disso, os caminhões em sua grande maioria apresentam uma baixa 
utilização de capacidade, aumentando também o custo de transporte. Esta situação gera igualmente a necessidade de jornada extraordinária dos colaboradores da equipe do recebimento, a fim de atender ao excesso de entregas. $\mathrm{O}$ alto volume de entregas está concentrado nos últimos dias do mês, ao contrário do início do mês quando é observada uma capacidade ociosa da equipe.

\section{Excesso de movimentação dos almoxarifes}

Nota-se um excesso de movimentações dos operadores (almoxarifes) durante a realização de suas atividades. O deslocamento para obtenção de ferramentas, materiais de apoio (cintas, paletes, grampos, etc), contribui para o aumento do tempo de realização de uma determinada atividade. Os próprios almoxarifes em entrevistas a equipe do projeto, reconheceram que muitas vezes é necessário se ausentarem dos postos de trabalho em busca de materiais de apoio ou ferramentas compartilhadas.

\section{Disponibilidade insuficiente dos equipamentos de movimentação}

Durante o processo de mapeamento do estado atual, foi comum observar equipamentos (empilhadeiras e paleteiras elétricas) não disponíveis, devido a avarias, desgastes, ou simplesmente problemas mecânicos, fato confirmado como usual pelos operadores. O supervisor do almoxarifado responsável por contactar a empresa prestadora do serviço de manutenção não é acionado de imediato pelos usuários. Em decorrência os equipamentos ficam indisponíveis por mais tempo prejudicando as atividades de operação. Durante o mapeamento do estado atual a taxa de disponibilidade dos equipamentos que atendem ao fluxo interno do almoxarifado é de aproximadamente 70\%.

\section{Alta ocupação do almoxarifado}

A alta taxa de ocupação do almoxarifado, especialmente nas estantes porta paletes, bloqueiam o fluxo de armazenagem devido a indisponibilidade de posições (endereços) para armazenagem. De acordo com o estudo do estado atual, a taxa de ocupação é de $90 \%$. 


\section{Acúmulo de materiais na área separação}

Após a etapa de separação dos materiais em estoque, estes ficam aguardando uma solicitação da área fabril, para que a transferência (entrega) seja realizada. No entanto, foi identificada falta de sincronia entre a separação (solicitada pelo PCP) e a necessidade da produção, gerando acúmulo de materiais já separados no almoxarifado (área de expedição). Com isso, é comum a interrupção do processo de separação por falta de espaço para acomodar novas peças separadas.

\subsection{2}

\section{Mapeamento do estado futuro}

A equipe do projeto concentrou-se inicialmente no entendimento dos desperdícios identificados na seção anterior, para em seguida através da aplicação dos conceitos lean, eliminá-los, e com isso, garantir um fluxo de materiais enxuto entre todas as atividades do almoxarifado central. Os kaizens e práticas gerenciais lean correspondentes aos desperdícios estão descritos na Tabela 10.

Tabela 10 - Kaizens/ práticas propostos por desperdício

\begin{tabular}{|l|c|}
\hline \multicolumn{1}{|c|}{ Desperdício } & Kaizen/Práticas \\
\hline Entregas de fornecedores não balanceadas. & Milk run \\
\hline Excesso de movimentação dos almoxarifes em busca de ferramentas. & 5S \\
\hline Disponibilidade insuficiente dos equipamentos de movimentação. & TPM \\
\hline Alta ocupação do almoxarifado. & Milk run \\
\hline Acúmulo de materiais na área de separação. & Kanban \\
\hline
\end{tabular}




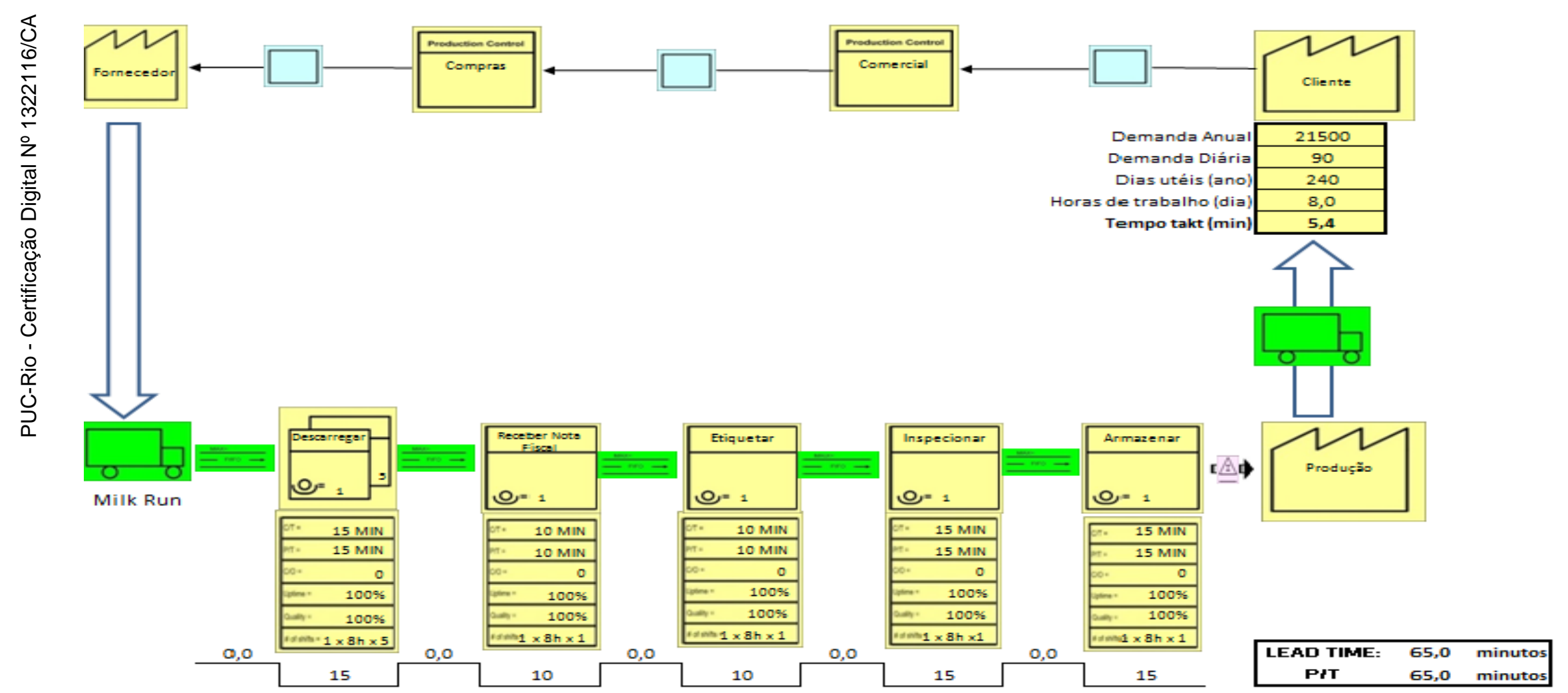

Figura 7 - MFV Estado futuro - fluxo de entrada 


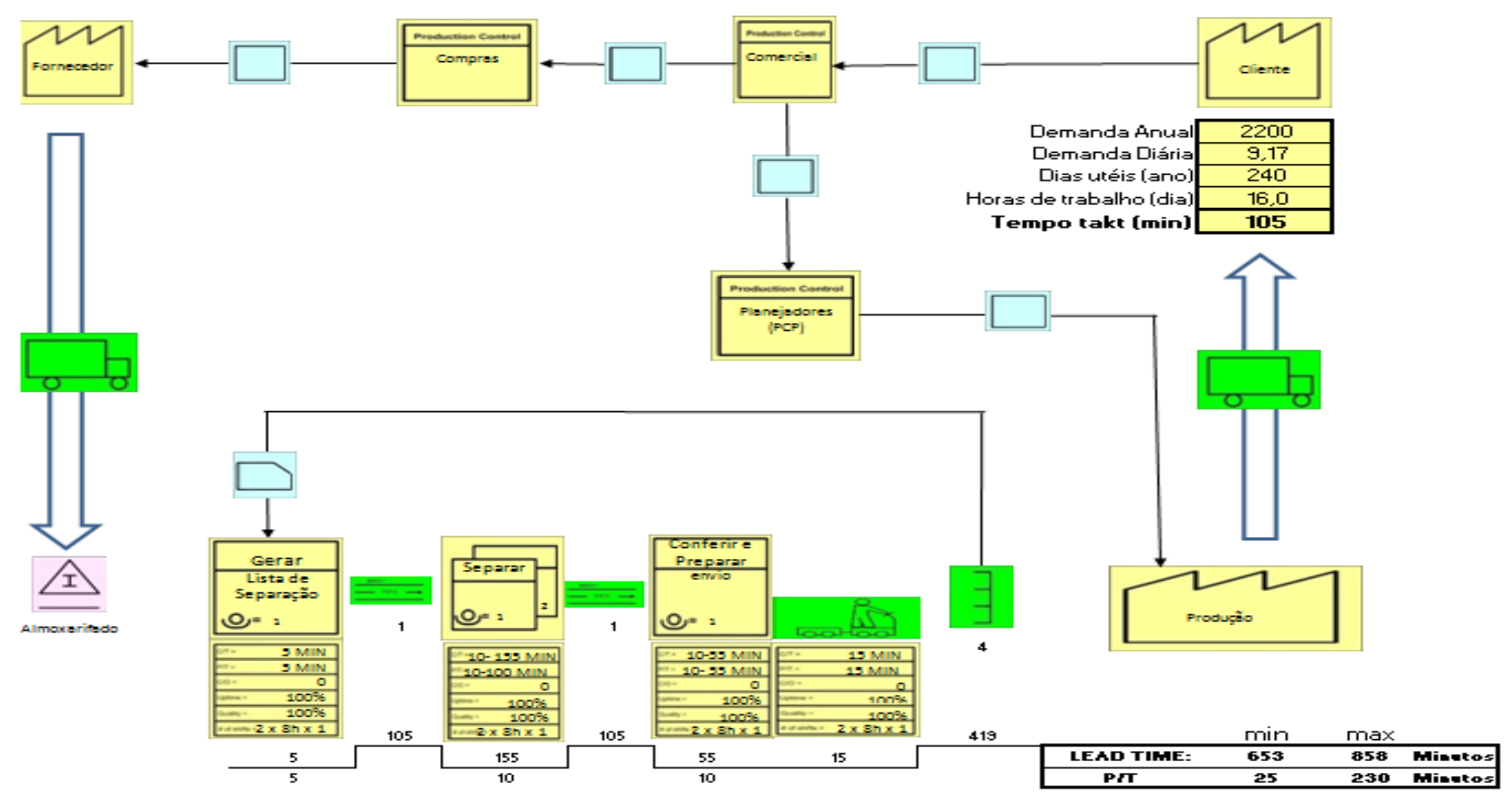

Figura 8 - MFV Estado futuro - fluxo de saída. 


\section{Estado futuro - fluxo de entrada}

A proposta do mapa estado futuro (Figura 7) visa eliminar o excesso de materiais em espera (fila) entre as atividades, estabelecendo um fluxo enxuto de materiais desde o recebimento até a armazenagem. A implantação de um sistema de entregas programadas, utilizando o conceito milk run, garante à empresa um controle do fluxo de recebimento dos materiais que são coletados nos fornecedores. A utilização do agendamento prévio de entregas alinhado à capacidade do fluxo de entrada e o estabelecimento de ilhas de FIFO (first in first out) entre os processos, limitado a uma determinada quantidade de materiais (correspondente a uma entrega padrão), irá garantir um fluxo com a espera (fila) de material reduzida a praticamente zero. A proposta de utilização do conceito milk run é detalhada abaixo.

\section{Utilização do modelo milk run na logística de entregas}

Com o objetivo de nivelar a freqüência de entregas dos materiais dos fornecedores, a equipe do projeto, propõem a migração do estado tradicional (entregas em grandes lotes e baixa freqüência) para a utilização do conceito milk run, aumentando a freqüência de entregas programadas, porém em lotes reduzidos.

A maior parte dos fornecedores da empresa está localizada na região da grande São Paulo e Campinas. Atualmente as entregas são realizadas pelos próprios fornecedores com o custo do frete como um componente do preço do material. A proposta é que esses materiais sejam coletados nos próprios fornecedores, por veículos contratados pela empresa, estabelecendo uma rota, garantindo a ocupação máxima do veículo, uma vez que diferentes materiais de variados fornecedores comporiam esse frete.

Uma análise do PPCP auxiliará na identificação da periodicidade das entregas conforme características das peças e na composição das cargas de materiais de cada rota. Com base no PPCP, os fornecedores serão classificados em termos de custos e volume do material e variedade dos desenhos (geometria das peças). 
A utilização do conceito milk run, com entregas programadas, permitirá um melhor nivelamento do trabalho no setor de recebimento físico visando a eliminação da jornada extraordinária, diminuição da insatisfação dos colaboradores, acúmulo de materiais na área de recebimento, além da ausência de filas de veículos no entorno da planta fabril. As entregas em pequenos lotes permitem também uma redução na taxa de utilização do almoxarifado, aumentando a disponibilidade de posições para a armazenagem de materiais. A programação de entregas será realizada levando-se em consideração a capacidade atual da área de recebimento. $\mathrm{O}$ agendamento de entregas que comprometam a capacidade diária do setor será tratado como exceção e somente autorizado pela gerência de almoxarifado.

\section{Estado futuro fluxo de saída}

A proposta para o estado futuro do fluxo de saída (Figura 8) visa estabelecer um sistema puxado de materiais entre as linhas de produção e o almoxarifado que elimine o estoque não controlado de materiais separados aguardando por uma solicitação de envio para a produção. A utilização do conceito de supermercado entre o almoxarifado e a produção, irá garantir um estoque limitado e controlado de materiais (ordens de produção), aguardando a coleta das linhas produtivas. No momento que os materiais referentes a uma ordem de produção são coletados no supermercado pela área de fabricação, um kanban é enviado para a que a supervisão do almoxarifado emita uma lista de separação e inicie o processo de separação para a reposição desses materiais no supermercado. O almoxarifado somente irá separar materiais visando à reposição do supermercado.

Baseado no estudo de movimentos e tempos estima-se uma redução de aproximadamente $20 \%$ no tempo de ciclo da atividade de separação, após a realização de algumas melhorias (kaizens) através da aplicação das ferramentas de TPM e 5S, conforme descrito a seguir. 


\section{Aplicação do TPM para equipamentos de movimentação}

A aplicação do TPM busca estabelecer um procedimento de manutenção preventiva nos equipamentos de movimentação (empilhadeiras e paleteiras elétricas), com o objetivo de aumentar a disponibilidade dos mesmos. A capacitação dos operadores nos procedimentos básicos de manutenção preventiva dos equipamentos resultará em uma melhor utilização dos mesmos. Ademais, a implantação do conceito de “dono” do equipamento contribuirá com o desenvolvimento da cultura de responsabilidade alinhada com a filosofia do “empoderamento”. A fim de facilitar o fluxo de informação entre os operadores e a supervisão será instalado um escaninho, para que os formulários de checagem diária (check list), devidamente preenchidos, sejam disponibilizados todos os dias, antes do início da jornada. Caso algum equipamento apresente algum problema que o operador não conseguisse resolver, este deverá disponibilizar o check list com a descrição da não conformidade em um escaninho destacado por uma fita vermelha. O equipamento deve ser identificado com uma placa padrão contendo os dizeres “Em manutenção” e a respectiva data inicial da indisponibilidade.

\section{$5 S$ no fluxo de almoxarifado}

Durante o mapeamento do estado atual, sobretudo na fase do estudo de tempos e movimentos, foi observado o excesso de movimentação dos operadores no fluxo (almoxarifes), que interrompiam suas atividades para buscar ferramentas, material de apoio, etc. Muitas vezes esses almoxarifes, se deslocam de suas estações de trabalho, várias vezes ao dia, percorrendo grandes distâncias, o que aumenta o tempo de interrupção da atividade.

A utilização dos conceitos de 5S no fluxo do almoxarifado visa eliminar as atividades que não agregam valor, entre as quais a busca por materiais, ferramentas e documentos, através do estabelecimento da organização e disciplina no ambiente de trabalho.

Partindo deste conceito, o time de projeto iniciou a jornada 5S, promovendo um mutirão de descarte na área de operação, onde os colaboradores foram incentivados a separar os materiais sem utilização. Como resultado várias ferramentas avariadas, caixas vazias, mobília avariada etc. foram destinadas para 
uma área de sucata. Os materiais segregados que de fato não seriam utilizados foram descartados.

Após essa etapa, a equipe realizou um levantamento das ferramentas necessárias para o desempenho de cada atividade, considerando os aspectos de segurança do trabalho e ergonomia. A partir desse estudo, algumas ferramentas foram adquiridas. Através de um investimento com custo muito baixo foi garantido a cada colaborador um conjunto de ferramentas básicas e de materiais para a realização das suas atividades. A partir daí, o próximo passo seria obter uma melhor forma de organizar e disponibilizá-los. Após estudar diversas maneiras, o grupo optou por uma estrutura tubular móvel (carrinho), onde as ferramentas e materiais seriam acondicionados em moldes. Esta solução permite identificar de forma rápida a ausência de uma ferramenta, garantindo um maior controle por parte do usuário. Esse carrinho é facilmente deslocado junto com o colaborador, caso este necessite se deslocar entre as estações de trabalho.

Todos os materiais de uso compartilhado foram identificados nas suas posições. Para materiais consumíveis foi criado um indicador de nível, onde ao atingir aquele nível uma reposição de material deverá ser solicitada à área de Compras. Esse nível já leva em consideração o tempo de reposição do fornecedor, evitando falta de materiais consumíveis.

A aplicação do 5S na área de operação reduzirá os deslocamentos dos colaboradores entre suas atividades e eliminará o tempo de busca e de espera pela disponibilidade de ferramentas.

\section{Sistema puxado através de kanban}

A implantação de um sistema puxado na conexão entre as linhas da fábrica com o almoxarifado central garantirá que os materiais sejam separados no momento certo, conforme sequência e necessidade do ponto de uso.

O sistema puxado permitirá um alinhamento entre as demandas das linhas de fábrica com o almoxarifado. Atualmente o almoxarifado inicia um processo de separação, baseado em um plano de produção, elaborado pela área de PCP. No entanto, esse plano mensal, muitas vezes, não reflete a realidade nas linhas de produção, isto é, atrasos, re-planejamentos, emergências etc. O objetivo do sistema puxado é de estabelecer uma conexão direta em tempo real, entre as linhas 
produtivas e o almoxarifado, que deixa de utilizar o plano de produção como um direcionador para iniciar o processo de separação dos materiais e passa a utilizar os cartões (kanban).

O kanban contém o tipo de ordem de produção para o qual o material deverá ser separado. O assistente de almoxarifado, ao receber um kanban, deverá consultar o sistema computacional e obter a lista de separação (picking list). As ordens de separação continuam sendo disponibilizadas no sistema computacional com antecedência pelo PCP, porém com o sistema puxado, somente serão separadas após o recebimento do kanban. Esse sistema garante que o almoxarifado separe apenas o que será consumido pela fábrica nas próximas horas, evitando assim, esforços desnecessários (horas extras) e acúmulo de materiais na área de expedição.

A utilização de um estoque controlado (supermercado) para o atendimento a diferentes de tipos de ordens de produção, entre o almoxarifado e as linhas de produtivas, irá garantir uma flexibilidade total ao sistema, já que o almoxarifado não precisará conhecer antecipadamente a sequência das ordens de produção que serão demandadas pelas linhas de fabricação.

\subsection{3}

\section{Trabalho padronizado}

Um importante conceito do lean é o trabalho padronizado. Em um ambiente de almoxarifado pouco automatizado em que grande parte das atividades são realizadas manualmente, garantir um padrão é um fator essencial.

A equipe do projeto, na fase de verificação do estado atual, principalmente no estudo de movimentos e tempos, observou que algumas atividades não eram realizadas de forma padrão. Era comum observar variações em uma mesma atividade. Algumas boas práticas adotadas de forma independente por alguns colaboradores não eram repassadas aos demais que realizavam aquela mesma atividade.

Com base nesse diagnóstico, o time do projeto, revisou procedimentos de trabalho e realizou o treinamento de toda a equipe do almoxarifado. Os colaboradores foram divididos conforme os setores de atuação (recebimento, 
armazenagem, separação e expedição) os procedimentos foram inicialmente discutidos, revisados (se necessário) e todos foram treinados.

A fim de garantir a aderência aos procedimentos padrão de trabalho e capturar possíveis melhorias de cada setor, foi instituído a função de líder, que além de realizar as tarefas diárias junto com os demais colaboradores do setor, deve atuar como um facilitador, promovendo a prática de kaizens no setor, acompanhando os indicadores e motivando os demais a atingir a meta estabelecida.

\subsection{4}

\section{Gestão Visual}

Baseado nos conceitos apresentados no Capítulo 3, a equipe de projetos, planeja introduzir no fluxo de materiais, elementos que permitam um controle visual das atividades, sinalizando principalmente possíveis atrasos ou interrupções indesejadas ao longo do fluxo.

No fluxo de entrada (recebimento até armazenagem), a utilização de sinais luminosos (andon) em cada estação de trabalho (guichês) da atividade de inspeção visa eliminar o deslocamento do inspetor de qualidade, pois caso surja alguma dúvida em relação à análise de algum material ou documentação, não será necessário o seu deslocamento da estação, já que ao acionar o sinal luminoso, o líder da inspeção irá de imediato até ao guichê de inspeção.

No fluxo de saída, a utilização de quadros brancos contendo os cartões (kanban) de separação de ordens, onde será possível visualizar o status de cada ordem (espera, em processo e finalizado). Os três quadros serão confeccionados com as grades de horários para que os cartões possam ser fixados conforme a seguinte convenção: em espera (grade de horários correspondente ao recebimento do cartão no almoxarifado), em processo (grade de horário correspondente ao inicio do processo de separação) e finalizado (grade de horário correspondente ao término do processo de separação). A grade de horários será dividida em intervalos de 30 minutos; Com isso se kanban for recebido no almoxarifado as 09h20min deve ser colocado no quadro “espera” na linha correspondente ao horário 09h30min, se a separação for iniciada as 10:30, o almoxarife antes de iniciar a separação deve removê-lo para o quadro "separação" e aloca-lo na linha 
correspondente as 10h30min, e esse mesmo almoxarife ao terminar a separação deve transferi-lo para o quadro "finalizado" correlacionando o kanban com o horário do termino do processo. O gestor do almoxarifado conseguirá através da visualização do status de cada ordem, verificar e corrigir possíveis atrasos no processo.

\subsection{5}

\section{Controle do desempenho ao longo do fluxo}

A implantação de ferramentas de controle visual busca facilitar o acompanhamento e controle do desempenho do fluxo de processo em comparação à meta (tempo takt) estabelecida, proporcionando ajustes (se necessários) para que a meta seja de fato atendida.

No fluxo de recebimento, o líder do fluxo irá disponibilizar em monitores (televisores) ao longo do fluxo, um gráfico comparativo entre número (volume) de paletes inspecionados e armazenados a cada 30 minutos e a meta (tempo takt). No fluxo de saída (separação), o líder do fluxo também irá disponibilizar um gráfico comparativo com o número (volume) de peças separadas a cada 30 minutos, seguindo o mesmo padrão adotado pelo fluxo de recebimento. Com isso, qualquer pessoa que visite o almoxarifado conseguirá identificar o desempenho do fluxo em relação à meta.

Em uma primeira etapa os dados de desempenho são extraídos pelo líder de cada fluxo diretamente do sistema de gestão integrado, no entanto, estuda-se uma solução alternativa junto à área de tecnologia da informação para que os gráficos sejam gerados de forma automática diretamente nos monitores do fluxo.

Com a utilização neste capítulo, dos conceitos e ferramentas lean descritas no Capítulo 3, obtêm-se uma migração do fluxo de materiais tradicional empurrado para um modelo enxuto, minimizando os desperdícios ao longo do fluxo. A redução do lead time quando comparados os mapas de fluxo de valor dos estados atuais e futuros comprovam a viabilidade da aplicação do conceito lean no almoxarifado. 


\section{Conclusões e recomendações}

No capítulo de Introdução foram apresentados a motivação e os objetivos do trabalho. O capítulo de Metodologia apresentou os dois componentes da dissertação: revisão sistemática da literatura e a pesquisa-ação. Seguiu-se a Fundamentação Teórica, descrevendo os principais conceitos necessários à pesquisa-ação. No Capítulo 4 (Pesquisa-ação), a aplicação do conceito lean nas operaçãoes de almoxarifado foi demonstrada. Nesta seção, as questões da pesquisa-ação serão revisitadas assim como o objetivo geral e específico a fim de garantir que esta dissertação atingiu o seu propósito. Por fim, serão apresentadas algumas recomendações.

A dissertação se propôs a responder as perguntas de pesquisa relatadas no Capítulo 1.

Os princípios e técnicas lean podem ser aplicados com êxito em serviços logísticos de armazenagem?

O trabalho demonstrou que os princípios do lean são perfeitamente aplicáveis no fluxo de materiais de um almoxarifado. Apesar das técnicas ainda não estarem totalmente implementadas, os mapas de valor (Figuras: 5, 6, 7 e 8) demonstram uma significativa redução do lead time nos fluxos de valor do estado futuro quando comparados aos fluxos de valor do estado atual.

Quais as técnicas de manufatura lean que melhor se ajustam às necessidades do almoxarifado?

O mapa de valor permite a identificação dos desperdícios ao longo do fluxo de materiais. O 5S estabelece um padrão de organização e disciplina importante para o desempenho das atividades de almoxarifado. O TPM aumenta a disponibilidade de recursos (equipamentos). O kaizen auxilia na redução do tempo de ciclo e consequentemente na obtenção de um menor lead time para todo o processo. O PPCP é a base para otimizar o fluxo, a partir do estudo das características dos materiais. O sistema milk run sincroniza e agrega as múltiplas entregas dos fornecedores. O controle visual permite a identificação de gargalos e 
colabora com uma melhor gestão de processos visando o atendimento ao tempo takt.

Quais as principais barreiras ou obstáculos para a implementação das ferramentas lean no almoxarifado?

A principal barreira a ser superada durante a fase da implementação é a concorrência de recursos (pessoas) com a operação de rotina do almoxarifado, pois em algumas ocasiões, reuniões foram canceladas devido à incompatibilidade de agendas, atendimento de urgências, visitas de clientes, auditorias etc. Inclusive algumas atividades de kaizen ficaram comprometidas pela indisponibilidade de recursos. Essa barreira não foi encontrada na literatura, foi identificada na prática, sendo uma contribuição deste trabalho. Outra barreira observada foi o baixo envolvimento inicial das áreas de interface as operações de almoxarifado (Planejamento, Compras e Produção), após um alinhamento entre a gerência do almoxarifado e as gerências dessas áreas essa barreira foi removida, com isso um suporte adequado ao projeto foi garantido.

A Seção 1.2 apresentou o objetivo geral e os objetivos específicos da dissertação. O objetivo geral que é a aplicação do conceito lean no fluxo de almoxarifado foi atingido conforme relatado na seção 4.2. Os objetivos específicos também foram alcançados. A dissertação apresentou uma pesquisaação demonstrando a aplicação do conceito lean. As principais ferramentas lean foram identificadas e aplicadas na pesquisa ação e as melhorias resultantes da aplicação lean foram indicadas, conforme seção 4.2.

Essa dissertação permitiu explorar o lean através da revisão sistemática da literatura e aplicá-lo na prática a partir de um protocolo de estudo de caso em uma organização pouco habituada com este conceito. Grande parte da equipe do projeto esteve pela primeira vez, exposta ao lean, o que trouxe um desafio a mais para a pesquisa-ação. No entanto, isso em nenhum momento foi identificado como uma barreira, o que demonstra a simplicidade do conceito e a adequação da proposta metodológica descrita no item 4 do protocolo de estudo de caso.

O próximo passo é a consolidação dos fluxos do estado futuro de entrada e saída, garantindo a migração por completo de um fluxo tradicional "empurrado" para um fluxo baseado no modelo enxuto. A aplicação do lean exige disciplina, assim como a manutenção do conceito no pós implementação. Recomendam-se visitas rotineiras ao gemba por parte da liderança sênior, como uma forma de 
verificar o desempenho da área, entender as dificuldades e estimular os colaboradores no aperfeiçoamento de suas atividades através das práticas lean.

A aplicação do lean, nesta pesquisa-ação, ficou restrita as operações de almoxarifado, porém durante o projeto evidenciou-se a necessidade de expandir a demais áreas da Logística (Compras e Planejamento). O almoxarifado é apenas uma parte integrante da cadeia de suprimentos, logo a extensão do conceito lean para os demais agentes da cadeia (incluindo os fornecedores diretos) é uma possibilidade que deve ser considerada pela empresa, a fim de obter uma vantagem competitiva.

Durante a fase de revisão sistemática da literatura, foi observada uma baixa disponibilidade de estudos sobre a aplicação do conceito lean em operações de almoxarifado. Esta dissertação deixa uma contribuição para futuros trabalhos acadêmicos que visam explorar o tema. Estudos bibliográficos sobre aplicações do lean em almoxarifados de outros setores produtivos complementariam o que foi analisado no setor de óleo e gás. Adicionalmente, estudos de caso e pesquisaação sobre a implementação dos princípios e métodos lean em almoxarifados contribuiriam para preencher as lacunas observadas na literatura acadêmica referente ao tema. 


\section{Referências bibliográficas}

AGUS, A.; HAJINOOR, M. Lean production supply chain management as driver towards enhancing product quality and business performance: Case study of manufacturing companies in Malaysia. International Journal of Quality \& Reliability Management, Vol. 29, n. 1, pp. 92-121, 2012.

AHUJA, S.; KHAMBA, S. Total productive maintenance: literature review and directions. International Journal of Quality \& Reliability Management, Vol. 25, n. 7, pp. 709-756, 2008.

AHUJA, S.; KUMAR, P. A case study of total productive maintenance implementation at precision tube mills. Journal of Quality in Maintenance Engineering, Vol. 15, n.3, pp.241 - 258, 2009.

AIE, International energy agency, Statistics 2011. Disponível em www.iea.org/stats. Acesso em 06 de junho de 2015.

ALARCON, L. Tools for the identification and reduction of waste in construction projects. Ed. Lean Construction, A.A. Balkema, Rotterdam, The Netherlands, 1997.

ALVES, C.; DINIS CARVALHO, J.; SOUSA, M. Lean production as promoter of thinkers to achieve companies' agility. The Learning Organization, Vol. 19, n. 3, pp. 219-237, 2012.

ANTONY, J. Reflective practice: six sigma vs lean. Some perspectives from leading academics and practitioners. International Journal of Productivity and Performance Management, Vol. 60 , n. 2, pp. 185-190, 2011.

ANVARI, A.; YUSSUF, R.; HOJJATI, S.; ISMAIL, Y. A proposed dynamic model for a lean roadmap. African Journal Business Management, Vol. 5, n. 16, pp. 6727-6737, 2011.

ARLBJORN, J.; FREYTAG, P. Evidence of lean: a review of international peer-reviewed journal articles. European Business Review, Vol. 25, n.2, pp. 174-205, 2013.

ARUNAGIRI, P.; GNANAVELBABU, A. Identification of Major Lean Production Waste in Automobile Industries using Weighted Average Method. Original Research Article Procedia Engineering, Vol 97, Pages 21672175, 2014.

AXELSSON, B.; ROZEMEIJER, F.; WYNSTRA, F. Developing Sourcing Capabilities: Creating Strategic Change in Purchasing and Supply Chain Management. John Wiley and Sons, West Sussex, 2005.

BAKER, P. Why is lean so far off?. Works Management, Vol. 8, pp. 6-15, 2002. 
BARRAZA-SUÁREZ, M.; RAMIS-PUJOL, J. An exploratory study of 5S: a multiple case study of multinational organizations in Mexico. Asian Journal on Quality, Vol. 13, n.1, pp.77 - 99, 2012.

BAYO-MORIONES, A.; BELLO-PINTADO, A.; MERINO-DIAZ-DECERINO, $\mathrm{J}$. The role of organizational context and infrastructure practices in JIT implementation. International Journal of Operations \& Production Management, Vol. 28 n. 11, pp. 1042-1066, 2008.

BAYO-MORIONES, A.; BELLO-PINTADO, A.; CERIO, J. $5 \mathrm{~S}$ use in manufacturing plants: contextual factors and impact on operating performance. International Journal of Quality \& Reliability Management, Vol. 27, n. 2, pp. 217-230, 2010.

BERG, A. Continuous improvement and kaizen: standardization and organizational designs. Integrated Manufacturing Systems, Vol. 8, n.2, pp.110 117, 1997.

BERG, J.; ZIJM, W. Models for warehouse management: Classification and examples. Original Research Article International Journal of Production Economics, Vol. 59, n. 1-3, Pages 519-528, 1999.

BHADURY, B. Management of productivity through TPM. Productivity, Vol. 41, n. 2, pp. 240-51, 2000.

BHAMU, J.; SANGWAN, S. Lean manufacturing: literature review and research issues. International Journal of Operations \& Production Management, Vol. 34, n. 7, pp. 876-940, 2014.

BHASIN, S.; BURCHER, P. Lean viewed as a philosophy. Journal of Manufacturing Technology Management, Vol. 17, n.1, pp. 56-72, 2006.

BHASIN, S. An appropriate change strategy for lean success. Management Decision, Vol. 50, n. 3, pp. 439-458, 2012.

CALARGE, F.A.; PEREIRA, F.H.; SATOLO, E.G. Evaluation of lean production system by using SAE J4000 standard: case study in Brazilian and Spanish automotive component manufacturing organizations. African Journal of Business Management, Vol. 6, n. 49, pp. 11839-11850, 2012.

CARLBORG, P.; KINDSTRÖM, D.; KOWALKOWSKI, C. A lean approach for service productivity improvements: synergy or oxymoron?. Managing Service Quality: an International Journal, Vol. 23, n.4, pp. 291-304, 2013.

CHAN, F.; CHAN, H. Improving the productivity of order picking of a manual-pick and multi-level rack distribution warehouse through the implementation of class-based storage. Expert Systems with Applications, Vol. 38, n.3, pp. 2686-2700, 2011.

CHAUHAN, G.; SINGH, T. Measuring parameters of lean manufacturing realization. Measuring Business Excellence, Vol. 16, n. 3, pp. 57-71, 2012. 
CHEN, Z.; SARKER, B. Multi-vendor integrated procurement-production system under shared transportation and just-in-time delivery system. J. Oper. Res. Soc., Vol. 61, pp. 1654-66, 2010.

COCOLICCHIO, B. Creating your lean future state. Quality Progress, Vol. 41, pp. 88-102, 2008.

CONNER, G. 10 questions. Manufacturing Engineering, Vol. 142, pp. 93-109, 2009.

COUGHLAN, P.; COGHLAN, D. Action research for operations management. International Journal of Operations \& Production Management, Vol. 22, n. 2, pp. 220-240, 2002.

COX, F.; BLACKSTONE, H. APICS Dictionary, 9th ed., APICS. The Educational Society for Resource Management, Falls Church, VA, 1998.

CUATRECASAS-ARBOS, L.; FORTUNY-SANTOS, J.; VINTRO-SANCHEZ, C. The operations time chart: a graphical tool to evaluate the performance of production systems e from batch-and-queue to lean manufacturing. Comput. Ind. Eng. 61(3), pp. 663-675, 2011.

DALAL, A. Keep it simple. Quality Progress, Vol. 43, pp. 24-32, 2010.

DANESE, P.; ROMANO, P.; BORTOLOTTI, T. JIT production, JIT supply and performance: investigating the moderating effects. Industrial Management \& Data Systems, Vol. 112, n. 3, pp. 441-465, 2012.

DE KOSTER, R. Design and control of warehouse order picking: A literature review. European Journal of Operational Research, 182(2), pp. 481-501, 2007.

DEIF, A.; ELMARAGHY, H. Cost performance dynamics in lean production leveling. Original Research Article Journal of Manufacturing Systems, Vol. 33, n. 4, pp. 613-623, 2014.

DEMETER, K.; MATYUSZ, Z. The impact of lean practices on inventory turnover. International Journal of Production Economics, Vol. 133, n. 1, pp. 154-163, 2011.

DORA, M.; KUMAR, M.; VAN GOUBERGEN, D.; MOLNAR, A.; GELLYNC, $X$. Operational performance and critical success factors of lean manufacturing in European food processing. SMEs Trends in Food Science \& Technology, Vol. 31, n. 2, pp. 156-164, 2013.

DUDEK-BURLIKOWASK, M. Quality research methods as a factor of improvement of preproduction sphere. Journal of Achievements in Materials and Manufacturing Engineering, Vol. 18, n. 18, pp. 435-438, 2006.

EMILIANI, L. Lean behaviours. Management Decision, Vol. 36, pp. 615-31, 1998. 
FRASER, D.; GONDIM, G. Da fala do outro ao texto negociado: discussões sobre a entrevista na pesquisa qualitativa. Paidéia, Vol. 14, n. 28, p. 139-152, 2004.

FRAZELLE, E. World-Class Warehousing and Material Handling. New York: McGraw-Hill, 2002.

FUENTES, F. Metodologia para inovação da gestão de manutenção industrial, thesis, $\mathrm{PhD}$ in Mechanical Engineering, Federal University of Santa Catarina, Florianópolis, 2006

GAMME, I.; ASCHEHOUG, S. Assessing lean's impact on operational integration. International Journal of Quality and Service Sciences, Vol. 6, n. 2/3, pp. 112-123, 2014.

GAPP, R.; FISHER, R.; KOBAYASHI, K. Implementing 5S within a Japanese context: an integrated management system. Management Decision, Vol. 46, n. 4, pp. 565-579, 2008.

GARDNER, L. Continuous improvement through $100 \%$ workforce engagement. Proceedings of the 11th Annual Total Productive Maintenance Conference and Exposition, Productivity, Dallas, TX, 2000.

GOETSCHALCKX, M.; ASHAYERI, J. Classification and design of order picking systems. Logistics World, pp. 99-106, 1989.

GONDHALEKAR, S.; BABU, S.; GODREJ, N. Towards TQM using kaizen process dynamics: a case study. International Journal of Quality \& Reliability Management, Vol. 12, n. 9, pp. 192-209, 1995.

GONZALEZ-R, P.L.; FRAMINAN, J.M.; PIERREVAL, H. Token-based pull production control systems: an introductory overview. Springer Science + Business Media, J Intell Manufacturing, pp. 5-22, 2012.

GU, J.; GOETSCHALCKX, M.; MCGINNIS, L. Research on warehouse operation: A comprehensive review. Original Research Article European Journal of Operational Research, Vol. 177, n. 1, pp. 1-21, 2007.

Research on warehouse design and performance evaluation: A comprehensive review. Original Research Article European Journal of Operational Research, Vol. 203, n. 3, pp. 539-549, 2010.

GUPTA, S.; JAIN, S. An application of 5S concept to organize the workplace ata scientific instruments manufacturing company. International Journal of Lean Six Sigma, Vol. 6, n. 1, pp. 73-88, 2015.

HALLGREN, M.; OLHAGER, J. Lean and agile manufacturing; external and internal drivers and performance outcomes. International Journal of Operations \& Production Management, Vol. 29, n. 10, pp. 976-999, 2009. 
HARRINGTON, H.J. Business Process Improvement: The Breakthrough Strategy for Total Quality, Productivity and Competitiveness. McGraw-Hill, New York, NY, 2000.

HARRIS, R.; HARRIS, C.; WILSON, E. Fazendo Fluir os Materiais: Um guia lean de movimentação de materiais para profissionais de operações, controle de produção e engenharia. Lean Institute Brasil, 2004.

HENDERSON, B.; LARCO, J. Lean Transformation. Oaklea Press, New York, NY, 2003.

HENN, S.; SCHMID, V. Metaheuristics for order batching and sequencing in manual order picking systems. Original Research Article Computers \& Industrial Engineering, Vol. 66, n. 2, pp. 338-351, 2013.

HICKS, B. Lean information management: Understanding and eliminating waste. Original Research Article International Journal of Information Management, Vol. 27, n. 4, pp. 233-249, 2007.

HINES, P.; RICH, N.; BICHENO, J.; BRUNT, D.; TAYLOR, D.; BUTTERWORTH, C.; SULLIVAN, J. Value stream management. The International Journal of Logistics Management, Vol. 9, n. 1, pp. 25-42, 1998.

HINES, P.; HOLWEG, M.; RICH, N. Learning to evolve. International Journal of Operations \& Production Management, Vol. 24, n. 10, pp. 994-1011, 2004.

HINES, P.; FRANCIS, M.; FOUND, P. Towards lean product lifecycle management: a framework for new product development. Journal of Manufacturing Technology Management, Vol. 17, n. 7, pp. 866-887, 2006.

HOFER, C.; EROGLU, C.; HOFER, A. The effect of lean production on financial performance: the mediating role of inventory leanness. International Journal of Production Economics, 138 (2), pp. 242-253, 2012.

HODGE, L.; GOFORTH, K.; JOINES, A.; THONEY, K. Adapting lean manufacturing principles to the textile industry. Production Planning \& Control, Vol. 22, n. 3, pp. 237-247, 2011.

HOPP, P.; SPEARMAN, L. To pull or not to pull: what is the question?. Manufacturing and Service Operations Management, Vol. 6, n. 2, pp. 133-148, 2004.

HOUSHMAND, M.; JAMSHIDNEZHAD, B. An extended model of design process of lean production systems by means of process variables. Robotics and Computer-Integrated Manufacturing, Vol. 22, n.1, pp. 1-16, 2006.

HUERTAS, J.; RAMÍREZ, J.; SALAZAR, F. Layout evaluation of large capacity warehouses. Facilities, Vol. 25, n. 7/8, pp. 259-270, 2007.

HUNTER, S. Ten steps to lean production. RDM Des Plaines, Vol. 76, pp. 20-5, 2004. 
IMAI, M. Gemba Kaizen: A Commonsense, Low-Cost Approach to Management. McGraw-Hill, Singapore, 2001.

JABBOUR, A.; JUNIOR, J.; JABBOUR, C. Extending lean manufacturing in supply chains: a successful case in Brazil. Benchmarking: an International Journal, Vol. 21, n. 6, pp. 1070-1083, 2014.

JADHAV, J.; MANTHA, S.; RANE, S. Exploring barriers in lean implementation. International Journal of Lean Six Sigma, Vol. 5, n. 2, pp. 122148, 2014.

JASTI, N.; SHARMA, A. Lean manufacturing implementation using value stream mapping as a tool. International Journal of Lean Six Sigma, Vol. 5, n. 1, pp. 89-116, 2014.

JENSEN, H.; JENSEN, H. Implementing of Lean manufacturing in SME companies. International Conference on Economic Engineering and Manufacturing Systems Brasov, Vol. 8 n. (21a), pp. 305-308, 2007.

JIMÉNEZ, E.; TEJEDA, A.; PÉREZ, M.; BLANCO, J.; MARTINÉZ, E. Applicability of lean production with VSM to the Rioja wine sector. International Journal of Production Research, Vol. 50, n. 7, pp. 1890-1904, 2011.

JIMÉNEZ, M.; ROMERO, L.; DOMÍNGUEZ, M.; ESPINOSA, M. $5 S$ methodology implementation in the laboratories of an industrial engineering university school. Original Research Article Safety Science, Vol. 78, pp.163-172, 2015.

JOHANSEN, E.; WALTER, L. Lean construction: prospects for the German construction industry. Lean Construction Journal, Vol. 3, n. 1, pp. 19-32, 2007.

JULIEN, D.; TJAHJONO, B. Lean thinking implementation at a safari park. Business Process Management Journal, Vol. 15, n. 3, pp. 321-335, 2009.

KATTMAN, B.; THOMAS, P.; MOORE, L.; WALSH, L. Visual workplace practices positively impact business processes. Benchmarking: An International Journal, Vol. 19, n.3, pp. 412-430, 2012.

KOLTZENBURG, T. The latitudes of lean. American Printer, Vol. 233, pp. 646, 2004.

KRAFCIK, J.F. Triumph of the lean production system. Sloan Management Review, n. 30, pp. 6-15, 1988.

KUMAR, M.; ANTONY, J.; SINGH, K.; TIWARI, M.; PERRY, D. Implementing the Lean Sigma framework in an Indian SME: a case study. Production Planning \& Control, Vol. 17, n. 4, pp. 407-423, 2006.

LAM, C.; CHOY, K.; CHUNG, S. A decision support system to facilitate warehouse order fulfillment in cross border supply chain. Journal of Manufacturing Technology Management, Vol. 22, n. 8, pp. 972-983, 2011. 
LEE, K.; WEI, C. Reducing molding changing time by implementing Lean Six Sigma. Interscience - Quality and Reliability Engineering International, Vol. 22, n. 4, pp. 432-451, 2009.

LIKER, J. Becoming Lean. Productivity Press, Portland, OR, 1996

The Toyota Way: 14 Management Principles form the World's Greatest Manufacturer. CWL Publishing Enterprises, New York, NY. Sundar, 2004.

LIKER, K.; WU, C. Japanese automakers, US suppliers and supply-chain superiority. Sloan Management Review, Vol. 42, n. 1, pp. 81-93, 2000.

LIKER, K.; CONVIS, L. The Toyota Way to Lean Leadership: Achieving and Sustaining Excellence Through Leadership Development, McGraw-Hill, New York, NY, 2011.

LIKER, K.; ROTHER, M. Why Lean Programs Fail. Lean Enterprise Institute, 2011.

LIM, M.; BAHR, W.; LEUNG, S. RFID in the warehouse: A literature analysis (1995-2010) of its applications, benefits, challenges and future trends. Original Research Article International Journal of Production Economics, Vol. 145, n. 1, pp. 409-430, 2013.

LUCATO, W.C.; CALARGE, F.A.; JUNIOR, M.L.; CALADO, R.D. Performance evaluation of lean manufacturing implementation in Brazil. International Journal of Productivity and Performance Management, Vol. 63, n.5, pp. 529-549, 2014.

MARTINÉZ-JURADO, P.; MOYANO-FLUENTES, J.; JEREZ-GOMEZ, P.; Human resource management in Lean Production adoption and implementation processes: Success factors in the aeronautics industry. Original Research Article BRQ Business Research Quarterly, Vol. 17, n. 1, pp. 47-68, 2014.

MATT, D.T. Adaptation of the value stream mapping approach to the design of lean engineer-toorder production systems. Journal of Manufacturing Technology Management, Vol. 25, n. 3, pp. 334-350, 2014.

MELTON, T. The Benefits of Lean Manufacturing: What Lean Thinking has to Offer the Process Industries. Original Research Article Chemical Engineering Research and Design, Vol. 83, n. 6, pp. 662-673, 2005.

MORGAN, G. Images of Organization. Sage Publications, London, 1997.

NABHANI, F.; SHOKRI, A. Reducing the delivery lead time in a food distribution SME through the implementation of six sigma methodology. Journal of Manufacturing Technology Management, Vol. 20, n. 7, pp. 957-974, 2009. 
NAJEM-AL, M.; DHAKAL, H.; LABIB, A.; BENNETT, N. Lean readiness level within Kuwaiti manufacturing industries. International Journal of Lean Six Sigma, Vol. 4, n. 3, pp. 280-320, 2013.

NEMOTO, T.; HAYASHU, K.; HASHIMOTO, M. Milk-run logistics by Japanese automobile manufacturers in Thailand. Original Research Article Procedia - Social and Behavioral Sciences, Vol. 2, n. 3, pp. 5980-5989, 2010.

OHNO, T. Toyota Production System: beyond Large Scale Production. Productivity Press, New York, NY, 1988.

OLAUSSON, D.; BERGGREN, C. Managing uncertain, complex product development in high-tech firms: in search of controlled flexibility, $R \& D$ Management, Vol. 40, n. 4, pp. 383-399, 2010.

ONÜT, S.; TUZKAYA, U.; BILGEHAM, D. A particle swarm optimization algorithm for the multiple-level warehouse layout design problem. Original Research Article Computers \& Industrial Engineering, Vol. 54, n. 4, pp. 783-799, 2008.

PEDERSEN, E.; HUNICHE, M. Determinants of lean success and failure in the Danish public sector: a negotiated order perspective. International Journal of Public Sector Management, Vol. 24, n. 5, pp. 403-420, 2011.

PEPPER, J.; SPEDDING, A. The evolution of Lean Six Sigma. International Journal of Quality \& Reliability Management, Vol. 27, n. 2, pp. 138-155, 2010.

PETTERSEN, J. Defining lean production: some conceptual and practical issues. The TQM Journal, Vol. 21, n. 2, pp. 127-142, 2009.

RAGHAVAN, V.; YOON, S.; SRIHARI, K. Lean transformation in a high mix low volume electronics assembly environment. International Journal of Lean Six Sigma, Vol. 5, n. 4, pp. 342-360, 2014.

RAHANI, A.; AL-ASHRAF, M. Production Flow Analysis through Value Stream Mapping: A Lean Manufacturing Process Case Study. Original Research Article Procedia Engineering, Vol. 41, pp. 1727-1734, 2012.

RAHMAN, N.; SHARIF, S.; ESA, M. Lean Manufacturing Case Study with Kanban System Implementation. Original Research Article Procedia Economics and Finance, Vol. 7, pp. 174-180, 2013.

RANSOM, C. Wall Street view of lean transformation. disponível em: www.Lean.org/events, 2008. Acesso em 05 de Jun. 2015.

RESTA, B.; POWELL, D.; GAIARDELLI, P.; DOTTI, S. Towards a framework for lean operations in product-oriented product service systems. Original Research Article CIRP Journal of Manufacturing Science and Technology, Vol. 9, pp. 12-22, 2015. 
ROHAC, T.; JANUSKA, M. Value Stream Mapping Demonstration on Real Case Study. Original Research Article Procedia Engineering, Vol. 100, pp. 520529, 2015.

ROLFSEN, M. A blueprint paradox: Successful but unintended crossnational translation of total productive maintenance. Journal of Quality in Maintenance Engineering, Vol. 20, n. 4, pp. 402-414, 2014.

ROTHER, M.; SHOOK, J. Aprendendo a Enxergar: mapeando o fluxo de valor para agregar valor e eliminar o desperdício. São Paulo: Lean Institute Brasil, 1999.

ROUWENHORST, B.; REUTTER, B.; STOCKRAHM, V.; HOUTUM, G.; MANTEL, R.; ZIJM, W. Warehouse design and control: Framework and literature review. Review Article European Journal of Operational Research, Vol. 122, n. 3, pp. 515-533, 2000.

RUSSEL, R.; TAYLOR, B. Operations Management, 2a. ed., Prentice-Hall, Upper Saddle River, NJ, 1999.

SAURIN, T.; MARODIN, G.; RIBEIRO, J. A framework for assessing the use of lean production practices in manufacturing cells. International Journal of Production Research, Vol. 49, pp. 32-51, 2011.

SHAH, R.; WARD, P. Defining and developing measures of lean production. J. Operat. Manag. 25 (4), 785e805, 2007.

SHANG, G.; PHENG, L. Understanding the application of Kaizen methods in construction firms in China. Journal of Technology Management in China, Vol. 8, n. 1, pp. 18-33, 2013.

Barriers to lean implementation in the construction industry in China. Journal of Technology Management in China, Vol. 9, n. 2, pp. 155-173, 2014.

SHINGO, S. A Study of the Toyota Production: From an Industrial Engineering Viewpoint. Cambridge: Productivity Press, Edição Revisada, 1989.

SINGH, B.; SHARMA, S. Value stream mapping as a versatile tool for lean implementation: an Indian case study of a manufacturing firm. Measuring Business Excellence, Vol. 13, n. 3, pp. 58-68, 2009.

SINGH, J.; SINGH, H. Kaizen Philosophy: A review of Literature. ICFAI Journal of Operations Management, 8(2), 51-72, 2009.

SINGH, B.; GARG, S.; SHARMA, S.; GREWAL, C. Lean implementation and its benefits to production industry. International Journal of Lean Six Sigma, Vol. 1, n. 2, pp. 157-168, 2010.

SINGH, R. Lean manufacturing: changing paradigms in product manufacturing, design \& supply. The Third International Conference on Quality Management, 1998. Disponível em: www.qmconf.com/Docs/singh98.pdf 
STAATS, B.; BRUNNER, D.; UPTON, D. Lean principles, learning, and knowledge work: Evidence from a software services provider. Original Research Article Journal of Operations Management, Vol. 29, n. 5, pp. 376-390, 2011.

STERNBERG, H.; STEFANSSON, G.; WESTERNBERG, E.; GENNÄS, R.; ALLENSTRÖM, E.; NAUSKA, M. Applying a lean approach to identify waste in motor carrier operations. International Journal of Productivity and Performance Management, Vol. 62, n. 1, pp. 47-65, 2013.

STYHRE, A. Kaizen, ethics, and care of the operations: management after empowerment. Journal of Management Studies, Vol. 38, n. 6, pp. 795-810, 2001.

SUNDAR, R.; BALAJI, A.; KUMMAR, S. A Review on Lean Manufacturing Implementation Techniques. Original Research Article Procedia Engineering, Vol. 97, pp. 1875-1885, 2014.

TAJ, S.; MOROSAN, C. The impact of lean operations on the Chinese manufacturing performance. Journal of Manufacturing Technology Management, Vol. 22, n. 2, pp. 223-240, 2011.

TAYLOR, D. Value chain analysis: an approach to supply chain improvements in agri-food chains. International Journal of Physical Distribution and Logistics Management, Vol. 35, n. 10, pp. 744-761, 2005.

TEICHGRABER, U.; BUCOURT, U. Applying value stream mapping techniques to eliminate non-value-added waste for the procurement of endovascular stents. European Journal of Radiology, 2012.

THOMÉ, A.; SCAVARDA, F.; FERNANDEZ, N.; SCAVARDA, A. Sales and operations planning: A research synthesis. International Journal of Production Economics, Vol. 138, n. 1, pp. 1-13, 2012.

THOMÉ, A.; HOLLMANN, R.; SCAVARDA, F. Research synthesis in collaborative planning forecast and replenishment. Industrial Management \& Data Systems, Vol. 114, n. 6, pp. 949-965, 2014.

TOLMASQUIM, M. Perspectivas e planejamento do setor energético no Brasil. Estudos avançados, Revista USP, vol. 26, no. 74, São Paulo, 2012.

TOMPKINS, J.A.; WHITE, J.A.; BOZER, Y.A.; TANCHOCO, J.M.A. Facilities Planning. Hoboken, NJ: John Wiley \& Sons, $4^{\circ}$ ed, 2010.

TRANFIELD, D.; DENYER, D.; SMART, P. Towards a methodology for developing evidence-informed management knowledge by means of systematic review. British Journal of Management, vol. 14, 207-222, 2003.

TRIPATHI, D. Influence of experience and collaboration on effectiveness of quality management practices: the case of Indian manufacturing, International Journal of Productivity and Performance Management, Vol. 54, n. 1, pp. 23-33, 2005 
TYAGI, S.; CHOUDHARY, A.; YANG, K.; CAI, X. Value stream mapping to reduce the lead-time of a product development process. Original Research Article International Journal of Production Economics, Vol. 160, pp. 202-212, 2015.

WAHAB, A.; MUKHTAR, M.; SULAIMAN, R. A Conceptual Model of Lean Manufacturing Dimensions. Original Research Article Procedia Technology, Vol. 11, pp. 1292-1298, 2013.

WATANABE-MAGNIER, R. Getting ready for kaizen: organizational and knowledge management enablers. VINE, Vol. 41, n. 4, pp. 428-448, 2011.

WAURZYNIAK, P. Lean automation. Manufacturing Engineering, Vol. 142, pp. 65-77, 2009.

WOMACK, J.; JONES, T.; ROSS, D. The Machine that Changed the World, Rawson Associates, New York, NY, 1990.

WOMACK, J.; JONES, D. Lean Thinking. Simon \& Schuster, New York, 1996.

WONG, C.; WONG, Y.; ALI, A. A study on lean manufacturing implementation in the Malaysian electrical and electronics industry. European Journal of Scientific Research, Vol. 38, n. 4, pp. 521-535. 2009.

WORLEY, J. The role of socio-cultural factors in a lean manufacturing implementation. Unpublished master thesis, Oregon State University, Corvallis, $\mathrm{OH}, 2004$.

WU, C. Lean manufacturing: a perspective of lean suppliers. International Journal of Operations and Production Management, Vol. 23, n. 11, pp. 13491376, 2003

YANG, T.; KUO, Y.; SU, C.T.; HOU, C.L. Lean production system design for fishing net manufacturing using lean principles and simulation optimization. Original Research Article of Manufacturing Systems, Vol. 34, pp. 66-73, 2015.

YIN, R. Case Study Research. Design and methods, USA. Sage Publications, Inc, 2003.

YOKOZAWA, K.; STEENHUIS, H. The influence of national level factors on international kaizen transfer. Journal of Manufacturing Technology Management, Vol. 24, n. 7, pp. 1051-1075, 2013.

ZAREI, M.; FAKHRZAD, M.; JAMALI, M. Food supply chain leanness using a developed QFD model. Original Research Article. J. Food Eng., 102 (1), 25e33, 2011. 


\section{Apêndice I}

\section{Protocolo do estudo de caso}

A meta-etapa de observação da pesquisa-ação segue os procedimentos de um estudo de caso em Engenharia de Produção e Operações e baseia-se na estrutura e conteúdo de protocolo de estudos de caso propostos por Yin (2003). O protocolo descreve os procedimentos de campo, questões de pesquisa-ação e propõe uma metodologia para implementação do lean nas operações de almoxarifado de uma empresa do setor de óleo e gás.

\section{1}

\section{Visão geral do estudo de caso}

O objetivo do estudo de caso é verificar a eficácia da implementação dos conceitos e ferramentas da manufatura lean em um almoxarifado de uma empresa fabricante de equipamentos do setor de óleo e gás.

A utilização de conceitos e ferramentas lean, tem como finalidade garantir um fluxo contínuo de materiais no almoxarifado, minimizando gargalos e desperdícios.

A equipe do projeto será composta por colaboradores do almoxarifado e áreas afins sendo suportados por um consultor externo, especialista no tema, que atuará como facilitador, apresentando metodologia, conceitos e ferramentas.

Trata-se de um estudo de caso simples onde o pesquisador atuará como observador participante uma vez que fará parte da equipe do projeto, caracterizando-se desta forma como uma pesquisa-ação. O estudo de caso torna-se desafiador uma vez que grande parte da equipe do projeto terá contato pela primeira vez com a abordagem do lean.

O protocolo apresentará uma metodologia para a implementação dos conceitos de manufatura lean, partindo do mapeamento de fluxo de valor atual. 


\section{2}

\section{Procedimentos de campo}

A pesquisa será realizada no almoxarifado da empresa estudada. Serão consideradas como pessoas atuantes: supervisores e líderes do almoxarifado bem como os almoxarifes que atuam diretamente no fluxo de processo a ser estudado.

Durante o período de cerca de 90 dias entre Fevereiro e Abril de 2015, serão observados e futuramente avaliados os fluxos de processo do almoxarifado central da empresa que englobam as atividades de recebimento, armazenagem e separação.

As informações obtidas em entrevistas e observações do entrevistador serão mantidas em sigilo. Não serão divulgados os nomes dos entrevistados bem como a razão social da empresa. Documentos que por ventura venham a fazer parte desse estudo não irão conter a identificação da empresa.

\section{3}

\section{Questões do estudo de caso}

i. Os princípios e técnicas do lean podem ser aplicados com êxito em serviços logísticos de armazenagem?

ii. Quais as técnicas da manufatura lean que melhor se ajustam às necessidades de almoxarifado?

iii. Quais as principais barreiras ou obstáculos para a implementação de ferramentas lean no almoxarifado?

\section{4}

\section{Proposta metodológica para a implementação do lean}

A metodologia utilizada para a aplicação dos conceitos do lean no almoxarifado será detalhada abaixo. 


\section{1 \\ Definição da equipe e plano de implementação}

Os patrocinadores (Alta Gerência) são responsáveis por garantir recursos financeiros para o estudo de caso conforme orçamento previamente aprovado e definir a missão e a visão. Além disso, terão o papel de remover barreiras que possam vir a comprometer o sucesso do estudo de caso.

O gerente do estudo de caso tem a responsabilidade de eleger um líder que ficará responsável por indicar os membros da equipe, prover substituição quando necessário, definir e acompanhar o plano de implementação e interagir com a equipe de execução realizando alterações quando necessário.

O líder do estudo de caso é responsável por coordenar as atividades do time, conforme plano de implementação previamente definido, solucionar conflitos entre os membros da equipe além de manter o engajamento de todos, reportando-se ao gerente de estudo de caso.

O plano de implementação deverá conter as atividades agrupadas em tópicos, com a indicação de um responsável, além de cronograma em um formato de fácil visualização.

A equipe será formada com membros permanentes ou fixos que apresentam sólidos conhecimentos dos processos da área de almoxarifado, além de um consultor externo que atuará como um facilitador, introduzindo conceitos e técnicas. A equipe de membros temporários será composta por colaboradores que atuam diretamente nos processos de almoxarifado ou em áreas com interface direta (fornecedores e clientes internos).

Recomenda-se que na equipe, sejam alocados colaboradores com perfil orientado para trabalho em equipe, alto grau de comprometimento, comunicação clara e objetiva, bons ouvintes (escuta ativa), proativos e flexíveis.

\section{2}

\section{Definição dos processos e da família de produtos}

A etapa inicial dessa jornada lean é a definição dos processos e famílias de produtos que serão foco do projeto. 
A equipe permanente do projeto com auxílio do consultor externo deverá listar todas as atividades desenvolvidas no macro processo de almoxarifado, desde recebimento de materiais do fornecedor até a entrega na linha de produção.

A definição dos processos será feita com base no fluxo contínuo, neste caso, os fluxos de entrada e de saída de material. Definimos o fluxo de entrada pelo conjunto de atividades realizadas desde recebimento do material na portaria da planta fabril até a colocação do mesmo em estoque, incluindo a inspeção de qualidade. O fluxo de saída inicia-se com a requisição do material em estoque até a entrega no ponto de uso na linha de produção.

Uma lista com todos os materiais cadastrados na empresa será utilizada como base para o agrupamento em famílias de produtos. A partir dessa lista será estruturado o plano para cada tipo de peça (PPCP), que nos permitirá conhecer as características de cada material como, por exemplo; local de uso e estocagem, embalagem recebida do fornecedor, freqüência de recebimento e de retirada, embalagem entregue no ponto de uso, tamanho e peso da embalagem utilizada.

No fluxo de recebimento, os materiais serão analisados individualmente, utilizando a planilha do plano para cada tipo de peça (PPCP) e a lista com todas as atividades percorridas por esses materiais dentro do fluxo de recebimento. Materiais com alta similaridade nas atividades do fluxo de recebimento e baixa variação máxima no tempo total de fluxo serão considerados partes de uma mesma família.

No fluxo de Saída de material serão considerados componentes de uma mesma família, materiais demandados em um mesmo tipo de ordem de produção. A equipe deverá obter a lista mestre de materiais para realizar essa classificação.

O passo seguinte, após a definição das famílias de produtos, é o calculo da demanda para cada família. Importante definir a unidade que será utilizada nesse cálculo (peças, paletes, lotes). No fluxo de recebimentos, a demanda será calculada com base nos pedidos de compras para um horizonte de 12 meses, fixos e planejados. No fluxo de entrega a base será as demandas futuras de ordens de montagem. Não é necessário que os fluxos de processo utilizem a mesma unidade de medida para o calculo de demanda. Os fluxos de recebimento e entrega (saída) são independentes.

Ainda nesta fase, a equipe do projeto deverá coletar dados importantes da operação de almoxarifado; planta baixa, número de colaboradores, organograma, 
quantidade de peças em estoque, tipos de locação para armazenagem, quantidade de posições de armazenagem.

\section{3}

\section{Treinamento da equipe}

O treinamento terá a duração de três dias sobre o mapeamento do fluxo de valor. O objetivo desse treinamento é de nivelar o conhecimento dos membros da equipe e capacitá-los para que possam mapear o fluxo de valor da área de almoxarifado contendo o estado atual e futuro.

No primeiro dia do treinamento serão apresentados os conceitos da metodologia lean, com foco especial na ferramenta de mapeamento de fluxo de valor. No segundo dia o grupo irá mapear o fluxo de valor atual para os processos e famílias de produtos definidos conforme item anterior. O terceiro e último dia estará reservado para o mapeamento do estado futuro.

Todos os colaboradores do almoxarifado serão treinados nos fundamentos básicos do lean e 5S. Esse treinamento será ministrado por um membro permanente da equipe do projeto durante as primeiras semanas do projeto.

\section{4}

\section{Mapeamento do fluxo de valor}

Após introdução dos conceitos básicos de lean, com foco especial no mapa de fluxo de valor, a equipe do projeto estará apta a iniciar o mapeamento do fluxo de valor com o suporte do consultor externo.

A equipe será encorajada a elaborar um mapa de fluxo de valor futuro, partindo do mapa de fluxo atual. Nesta etapa não é esperado que a equipe apresente um mapa final, mas sim um esboço que será revisado durante a pesquisa.

A fim de facilitar o desenho dos fluxos de valor, a equipe da pesquisa será dividida em grupos por processos. Além disso, canetas esferográficas na cor azul e preta e um Kit com adesivos autocolantes ilustrados com as figuras que compõe o fluxo de valor, estarão disponíveis a cada grupo. Um papel em formato $1,5 \mathrm{~m} \mathrm{x}$ 1m também servirá de base para a confecção do fluxo. 
O conceito de takt time deverá ser bastante discutido nesta etapa uma vez que é um componente importante no mapeamento de fluxo de valor. Através dele, será definida a freqüência ou ritmo dos fluxos de processo.

Ao final do mapeamento do estado atual e futuro, os grupos farão uma apresentação de 15 minutos cada relatando as diferenças entre cada um dos fluxos. Nessa etapa já serão visualizadas algumas oportunidades de melhorias no fluxo de valor.

\section{5}

\section{Estudo de tempos}

Com o estado atual e futuro mapeados, a próxima etapa é o estudo de tempos, onde os grupos acompanharão o fluxo de materiais, descrevendo as atividades e movimentações envolvidas no processo e medirão o tempo de realização de cada atividade.

Cada grupo receberá uma planilha com as informações e instruções para o correto preenchimento.

Importante que esse mapeamento não seja concentrado em apenas um dia, devendo ocorrer em dias e horários diferentes, medindo a mesma atividade com diferentes executores. Isso permitirá que a variação de tempo entre executores de uma mesma atividade seja capturada.

\section{6}

\section{Entrevistas}

A equipe permanente do estudo de caso, em posse do fluxo de valor atual e do estudo de tempos, deve nesta fase entrevistar os operadores do fluxo. O objetivo desta fase é coletar informações sobre o fluxo atual, a partir da descrição das atividades realizada no estudo de tempos.

Fraser e Gondim (2004) citam como vantagens do processo de entrevistas o fato desta favorecer uma relação intersubjetiva entre pesquisador e entrevistado, por meio de trocas verbais e não verbais, permitindo um maior entendimento da opinião e percepções das pessoas. 
São convidados para essa etapa os operadores envolvidos nos dois processos que estão sendo mapeados: recebimento e entrega. Porém recomenda-se que as entrevistas sejam realizadas em separado para cada processo. Caso a equipe de operadores envolvidos no fluxo seja muito grande, deve-se eleger representantes.

Tópicos aborados durante as entrevistas:

- Descrever a(s) atividade(s) que o colaborador executa.

- Relatar as principais dificuldades.

- Elencar as principais entradas (insumos, informação) e saídas (resultados) da sua atividade.

Nesta etapa a equipe permanente deve eleger um representante para realizar anotações que posteriormente serão analisadas. Como preparação para esta entrevista, a equipe deverá rever o desenho do fluxo atual, juntamente com os formulários do estudo de tempos preenchidos. Todos devem estar bem atentos, e evitar interromper o entrevistado durante a explanação. É Importante manter o foco, sem permitir que o entrevistado desvie do tema. Nessa etapa ainda não é o momento de discutir melhorias nos processos, apenas relatar a situação atual. Recomenda-se que essa entrevista ocorra em um local silencioso com boa iluminação e com temperatura agradável. A duração desta entrevista varia conforme complexidade dos processos, no entanto podem ocorrer em diversos períodos para que não fique cansativo para os entrevistados.

\section{7}

\section{Análise do fluxo atual}

Já em posse do fluxo atual revisado, após estudo de tempos e entrevistas com operadores, a equipe do estudo de caso irá iniciar a análise desse fluxo. Inicialmente definindo as métricas chaves de cada processo e calculando os valores atuais para essas métricas.

A equipe deverá listar todas as oportunidades de melhoria capturadas visando atingir ao estado futuro, sempre focando nos sete desperdícios que formam a base do conceito do lean. 
Denominaremos essa lista de planilha Kaizen. O formato desta planilha deverá conter a ação, área envolvida, responsável, prioridade e prazo. Importante mencionar que se trata de uma lista dinâmica que será revisada ao longo do projeto, podendo acrescentar ou excluir ações.

A planilha kaizen, muito provavelmente trará ações para área de suporte (Tecnologia da Informação, Recursos Humanos, Manutenção, etc). Caso essas áreas não estejam representadas no time da pesquisa-ação, é importante o envolvimento imediato a fim de garantir o cumprimento das ações. Recomenda-se uma apresentação do escopo da pesquisa para os responsáveis dessas áreas a fim de obter o engajamento necessário.

\section{8}

\section{Revisão do fluxo de valor futuro}

Após a análise do fluxo atual e revisão do leiaute, a equipe deverá revisar o desenho do fluxo de valor futuro, elaborado na etapa de mapeamento de fluxo de valor.

As melhorias listadas na planilha kaizen e a revisão de leiaute, já estarão repercutidas nessa revisão do fluxo. Atingir a esse novo mapa de valor futuro é o objetivo maior do projeto de implementação do lean. 